\title{
Formation of the Flatreef deposit, northern Bushveld, by hydrodynamic and hydromagmatic processes
}

\author{
W. D. Maier ${ }^{1}$ (D) K. E. L. Abernethy ${ }^{1}$ • D. F. Grobler ${ }^{2} \cdot$ G. Moorhead ${ }^{3}$
}

Received: 4 May 2019 / Accepted: 5 May 2020 / Published online: 2 July 2020

(C) The Author(s) 2020

\begin{abstract}
New lithological and whole rock compositional data show that the main platinum-group element (PGE) horizons of the Flatreef succession show strong compositional similarities to the Merensky and Bastard reefs of the western Bushveld Complex (WBC), notably in terms of many immobile and incompatible minor and trace elements such as $\mathrm{TiO}_{2}, \mathrm{Zr}, \mathrm{Y}$, and $\mathrm{REE}$. However, $\mathrm{Al}_{2} \mathrm{O}_{3}$, $\mathrm{CaO}$, and $\mathrm{Na}_{2} \mathrm{O}$ contents are markedly lower in the Flatreef, whereas $\mathrm{MgO}$ contents are higher. In view of broadly similar silicate mineral compositions in the Flatreef and the WBC reefs, we suggest that the major element compositional differences between the rocks are largely due to higher modal proportions of orthopyroxene and olivine and lower proportions of plagioclase in the Flatreef. The thickness of the mineralised interval is much greater in the Flatreef than in the WBC (several $10 \mathrm{~s} \mathrm{of} \mathrm{m} \mathrm{vs} \sim 1 \mathrm{~m}$ ) and the abundance of sulfides in the Flatreef is typically somewhat higher (on average $\sim 1.5 \%$ vs $\sim 1 \%$ ). These data, complemented by textural observations, are interpreted to reflect enhanced hydrodynamic crystal sorting accompanied by percolation of sulfide melt through incompletely solidified cumulates. Further genetic constraints are provided by metal data: The concentration of Ni $(\sim 3000 \mathrm{ppm})$ in the Flatreef is broadly similar to that in the Merensky Reef of the WBC, but $\mathrm{Cu}$ contents are markedly higher (average $\sim 1500 \mathrm{ppm}$ vs $700 \mathrm{ppm}$ in the WBC). The concentrations of most PGE are slightly lower (Flatreef $\sim 1.5-2 \mathrm{ppm}$ Pt, $\sim 100-150 \mathrm{ppb}$ Rh; WBC MR 3.7 ppm Pt, 240 ppb Rh), but Pd has broadly similar contents (Flatreef $\sim 1.2-2 \mathrm{ppm}$; WBC MR $1.54 \mathrm{ppm})$. The relatively high $\mathrm{Cu}$ content of the Flatreef is interpreted as a result of assimilation of $\mathrm{Cu}$ sulfides from the sedimentary floor rocks. The reason for the enrichment of Pd relative to Pt, especially in the basal rocks, remains unclear. It could reflect mobilisation of Pd via a fluid phase from the country rocks or the interior of the intrusion, relatively enhanced partitioning of Pd into the sulfides, or relative Pt depletion of the earliest magma pulses in response to Pt alloy fractionation triggered by contamination with reducing country rocks.
\end{abstract}

Editorial handling: P. J. Jugo

Electronic supplementary material The online version of this article (https://doi.org/10.1007/s00126-020-00987-5) contains supplementary material, which is available to authorized users.

W. D. Maier

maierw@cardiff.ac.uk

1 School of Earth and Ocean Sciences, Cardiff University, Cardiff CF10 3AT, UK

2 Ivanplats Ltd, Mokopane, South Africa

3 CSIRO, Mineral Resources, Private Bag 10, Clayton South, Victoria 3169, Australia

\section{Introduction}

Grobler et al. (2019) used a 700-km drill core database to document the stratigraphy of the "Flatreef", a highly mineralised, flattened portion of the Platreef located downdip of previous mining and exploration operations in the northern lobe of the Bushveld Complex (Fig. 1 in Maier et al. 2020). In contrast to the relatively poorly layered Platreef, the Flatreef shows more regularly layered reefs of the type found in the western and eastern Bushveld Complex (WBC and EBC), including the Merensky Reef (MR) and UG2 chromitite. These findings suggested that many of the processes responsible for the formation of the MR and UG2 equally controlled the formation of the Flatreef (Grobler et al. 2019). In the present paper, we use the extensive diamond drill core database from the Flatreef to place further constraints on these processes. 


\section{Geological setting and igneous stratigraphy}

The Flatreef was intersected during exploration drilling on the farm Turfspruit, within the south-central sector of the northern limb, some $20 \mathrm{~km}$ to the $\mathrm{N}$ of Mokopane. The geological setting and igneous stratigraphy of the Flatreef have been presented in detail by Grobler et al. (2019) who correlated the most mineralised sequence of the Flatreef to the Upper Critical Zone (UCZ) of the WBC (Fig. 1). However, the Flatreef is much more mineralised (up to $4.5 \mathrm{ppm}$ platinum-group element (PGE) over $90 \mathrm{~m}$ ) than the Merensky and UG2 reefs of the WBC (each typically 5-8 ppm over $\sim 1 \mathrm{~m}$ ), and more contaminated resulting in abundant xenoliths and rafts of the floor rocks and reduced lateral continuity of layering.

The lowermost igneous rocks of the Bushveld Complex at Turfspruit consist of Lower Zone (LZ) ultramafic rocks that intruded, in a sill-like manner, into shales and dolomites of the Duitschland Formation. Next is the Flatreef, which is separated from the LZ by a screen of sedimentary rocks of variable thickness (metres to $100 \mathrm{~s}$ of metres). The basal Flatreef rocks typically consist of relatively poorly mineralised $(<1 \mathrm{ppm}$ PGE), strongly contaminated pyroxenite and norite. Thick intervals of calcsilicate may represent large xenoliths or floor remnants and roof pendants. This contaminated interval, termed the Footwall
Assimilation Zone (FAZ), is overlain by the main mineralised interval which consists of a package of rocks containing interpreted correlatives of the UG2 chromitite and the Merensky and Bastard reefs. The recognition of this stratigraphic correlation at the mine matured over the course of several years of exploration. Thus, the $\sim 1-\mathrm{m}$ thick chromitite seam in the Flatreef was originally called "Main Chromitite" but has now been renamed UG2 chromitite (Grobler et al. 2019). The overlying main sulfide mineralised interval was initially called "T2" or "Main Reef" but is now referred to as Merensky Reef, and the uppermost mineralised interval was initially called "T1" or "Upper Reef", but is now called Bastard Reef (Yudovskaya et al. 2017a; Grobler et al. 2019).

The Merensky Reef in the Flatreef succession typically comprises a basal $\mathrm{Cr}$ stringer, overlain by layers of pegmatoidal harzburgite termed $\mathrm{M} 1_{\mathrm{L}}$ and/or pegmatoidal orthopyroxenite termed $\mathrm{M}_{\mathrm{U}}$ (the subscripts $\mathrm{L}$ and $\mathrm{U}$ denoting "lower" and "upper", but note that in some drill cores harzburgitic $\mathrm{M} 1_{\mathrm{L}}$ can be above orthopyroxenitic $\mathrm{M} 1_{\mathrm{U}}$ ), a second $\mathrm{Cr}$ stringer, and medium-grained pyroxenite (termed M2), all of which may contain several percent PGE-rich sulfides (Fig. 2). The Merensky Reef is overlain by poorly mineralised or barren pyroxenite and/ or norite (termed the Middling unit), and then by the Bastard Reef (Grobler et al. 2019).
Fig. 1 Proposed stratigraphic correlation of Flatreef with uppermost $\mathrm{CZ}$ in WBC (from Grobler et al. 2019)

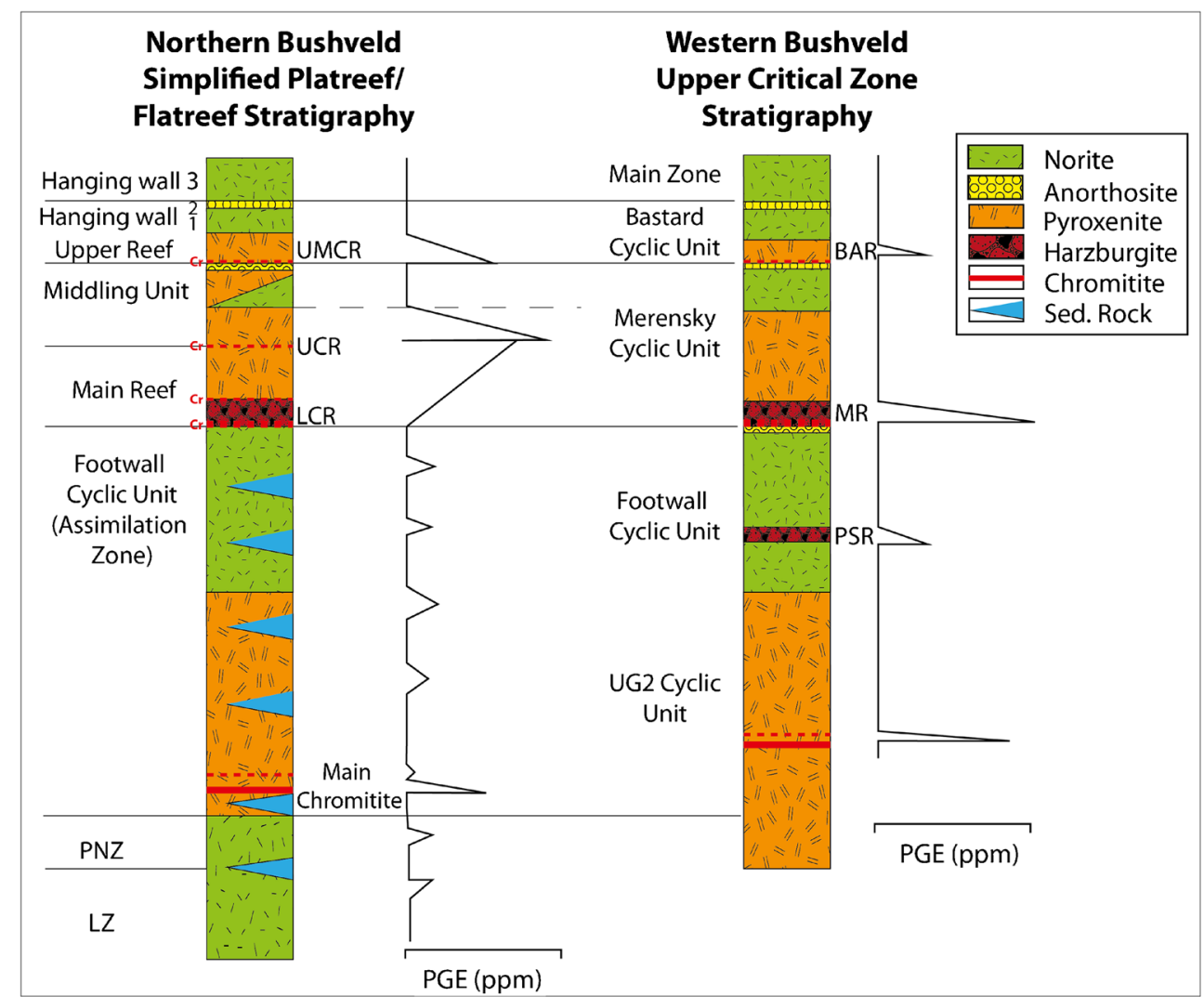


Fig. 2 Examples of Merensky reef lithologies from the Flatreef. a Drill core UMT402, 793 m, showing M2 with basal chromitite stringer, and then $\mathrm{M}_{\mathrm{U}}$ underlain by harzburgitic $\mathrm{M} 1_{\mathrm{L}}$. Note concentration of olivine in plagioclase network. b Drill core UMT448, $811 \mathrm{~m}$, showing M2 with thin basal $\mathrm{Cr}$ stringer, $20 \mathrm{~cm}$ of $\mathrm{M}_{\mathrm{U}}$, underlain by harzburgitic $\mathrm{M}_{\mathrm{L}}$
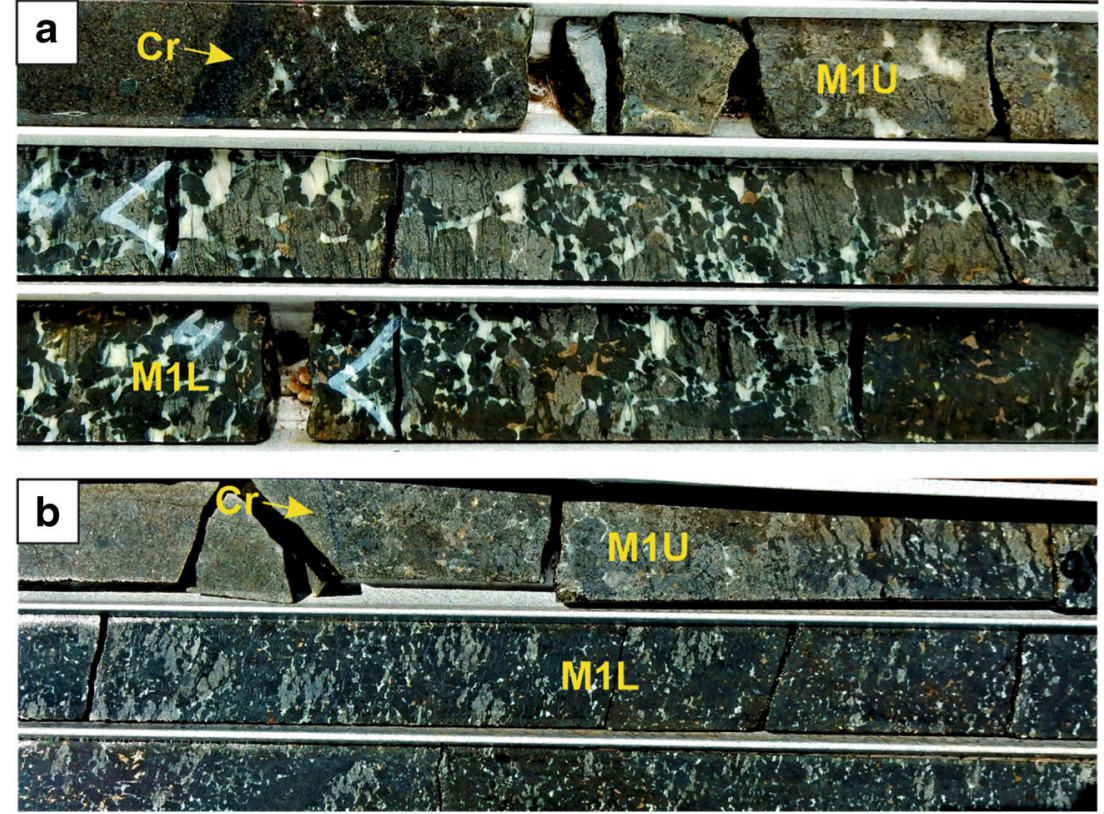

\section{Methods}

In total, approximately $700 \mathrm{~km}$ of diamond drill core are available for study on the Turfspruit project. The deepest drill holes extend to $>1800-\mathrm{m}$ depth (Abernethy et al. 2020). Approximately 340 drill cores intersected the Flatreef, and 251,000 samples were assayed for Pt, Pd, and $\mathrm{Rh}$ as well as $\mathrm{Au}, \mathrm{Cu}, \mathrm{Ni}, \mathrm{Cr}$, and $\mathrm{S}$. Lithophile major elements as well as a range of lithophile trace elements were determined for the reef intersection in 20 selected drill cores that are considered to represent a range of typical reef sequences (see Fig. 1 of Maier et al. (2020) for borehole locations). Rare earth elements were analysed in six of these drill cores (UMT 314, 336, 341D, 345, 378, and 390, 670 samples in total), and all six PGE (Os, Ir, Ru, Rh, Pt, Pd) were analysed in 116 samples. Average metal contents of $\mathrm{BAR}, \mathrm{M} 2, \mathrm{M} 1_{\mathrm{U}}$, and $\mathrm{M} 1_{\mathrm{L}}$ are listed in Table 1.

The concentrations of whole rock major elements were determined by XRF, S by LECO combustion, and base metals and precious metals by multi-acid digestion followed by ICPMS and OES. Further details of the methods are outlined in Grobler et al. (2019). X-ray fluorescence (XRF) scanning microscopy was performed on the Maia Mapper laboratory XRF imaging system at CSIRO Mineral Resources, Clayton Victoria. The Maia Mapper (Ryan et al. 2018) comprises an Excillum D2 Liquid Metal Jet high brightness laboratory Xray source (Larsson et al. 2011), a polycapillary X-ray focussing lens (www.xos.com), a 384-element Maia large solid angle $(1.3 \mathrm{sr}) \mathrm{X}$-ray detector array (Siddons et al. 2014) mounted in a coaxial back-scatter configuration, and a custom sample presentation and transport system designed for mineral samples up to $50 \mathrm{~cm}$ in length. The metal jet source was operated at $70 \mathrm{kV}$ producing a broadband X-ray spectrum from its Ga-In-Sn liquid target, focused to an approximately $30-\mu \mathrm{m}$ beam spot on sample. The sample was raster scanned in fly-scan mode with equivalent pixel sizes of $30 \times 30 \mu \mathrm{m}$ with full spectral data acquired at an effective $12 \mathrm{~ms}$ per image pixel. The quantitative multi-element images were produced using the dynamic analysis method with the CSIRO GeoPIXE software (Ryan 2000) maintaining the full spatial resolution for $\sim 10 \mathrm{M}$ pixel images for these samples. A standard sample manufactured by NIST (NIST 2012) was imaged between each mineral sample for calibration and fluence measurement and quality control. The procedures used to generate the false colour XFM element maps are described in Barnes et al. (2018).

\section{Results}

\section{Petrography}

Results of microXRF analysis of a coarse-grained Flatreef orthopyroxenite from the M2 reef in drill core TMT 006 are shown in Fig. 3. Approximate model proportions are up to $\sim 80 \%$ orthopyroxene, $\sim 10 \%$ clinopyroxene and plagioclase each, a few $\%$ sulfides, up to $1 \%$ phlogopite, and trace amounts of chromite. The image highlights a number of interesting textural features, including the mostly euhedral or subhedral habit of orthopyroxene, the subhedral habit of several of the large (oikocrystic) clinopyroxene crystals containing small orthopyroxene inclusions, and the location of the chromite crystals within interstitial plagioclase. The sulfides occur in patchy disseminated form in the interstitial space 


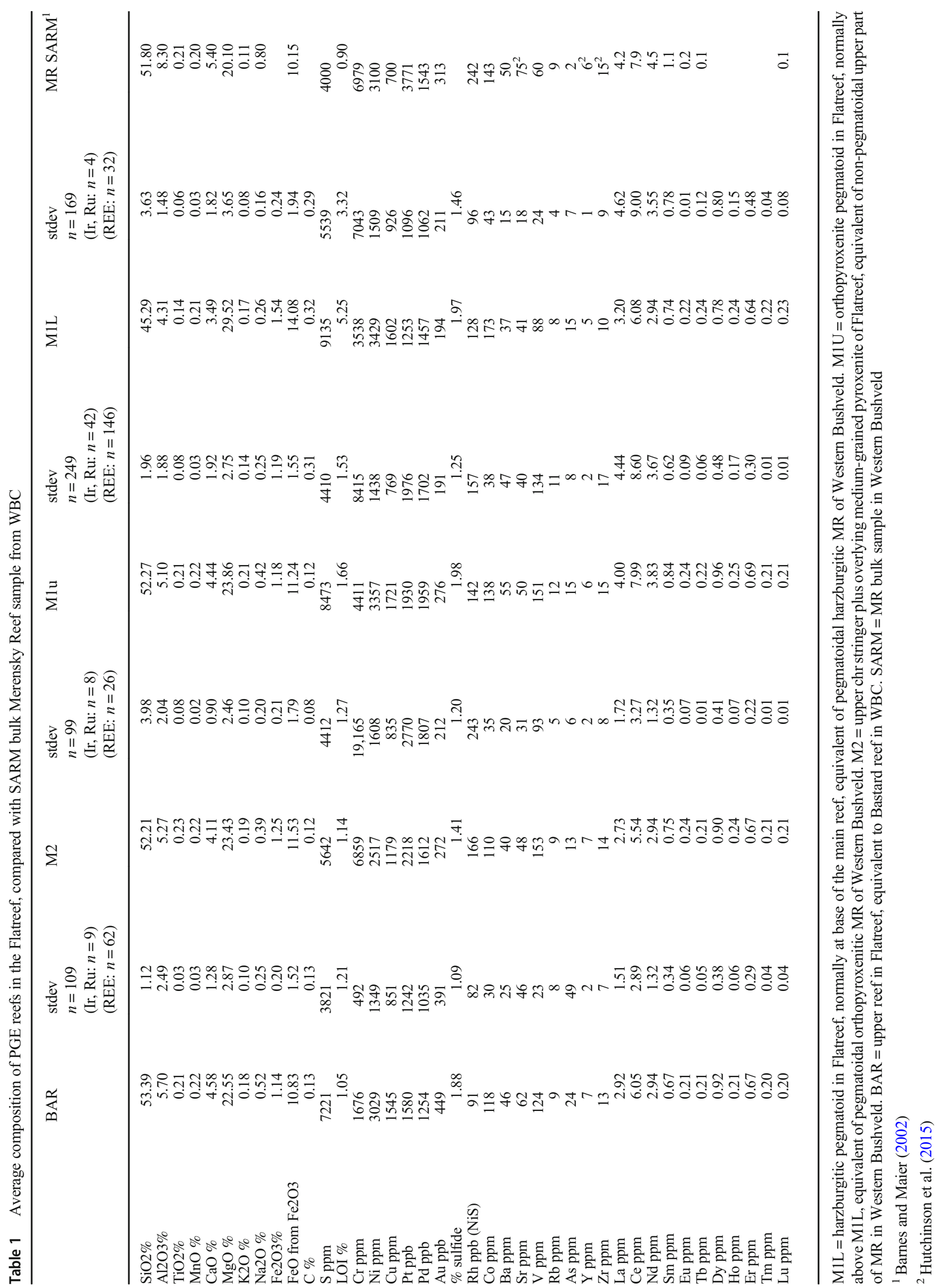




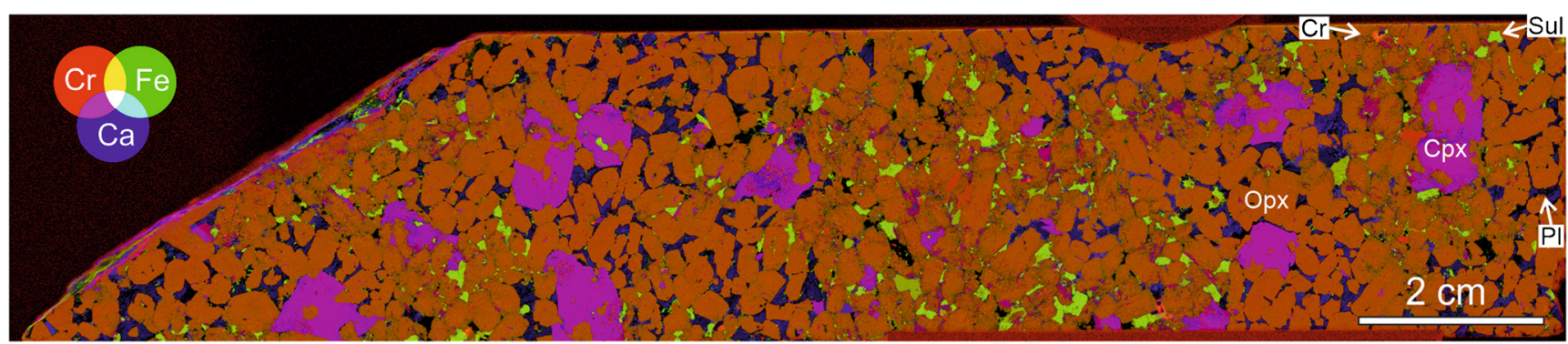

Fig. 3 MicroXRF maps indicating sulfide percolation in M2, sample 818.43, drill core TMT006. Pink = clinopyroxene, orange = orthopyroxene, dark blue $=$ plagioclase, green $=$ sulfide

showing early-formed sulfide-free oikocrysts, sulfides in face contact with the cumulus pyroxenes, and centimetre-scale domains where all the interstitial space is filled with sulfide separated by patches where none of it is.

\section{Average composition of the reefs}

In terms of lithophile elements, the PGE reefs of the Flatreef show certain compositional similarities to the Merensky Reef in the WBC, notably in terms of many immobile and incompatible minor and trace elements such as $\mathrm{TiO}_{2}, \mathrm{Zr}, \mathrm{Y}$, and REE (Table 1, and Abernethy et al. 2020). However, the concentrations of the major elements $\mathrm{Al}_{2} \mathrm{O}_{3}, \mathrm{CaO}$, and $\mathrm{Na}_{2} \mathrm{O}$ contents are markedly lower in the Flatreef, whereas $\mathrm{MgO}$ and $\mathrm{K}_{2} \mathrm{O}$ contents are higher than in the WBC Merensky Reef. The average sulfide content of the Flatreef is somewhat higher than in the Merensky Reef of the WBC $(\sim 1.5-$ $2 \%$ vs $\sim 1 \%)$. Nickel and Pd contents of the Flatreef are broadly similar to those in the MR of the WBC $(\sim 3000 \mathrm{ppm} \mathrm{Ni}, \sim 1.5-2 \mathrm{ppm} \mathrm{Pd})$, but $\mathrm{Cu}$ contents are markedly higher (average $\sim 1500 \mathrm{ppm}$ vs $700 \mathrm{ppm}$ ) resulting in higher $\mathrm{Cu} / \mathrm{Ni}$ and $\mathrm{Cu} / \mathrm{Pd}$, and $\mathrm{Pt}$ contents are lower ( $\sim 2 \mathrm{ppm}$ vs $3.7 \mathrm{ppm})$, resulting in lower Pt/Pd. Comparison of the 2 pegmatoidal units indicates that $\mathrm{M} 1_{\mathrm{L}}$ tends to have mostly lower chalcophile (PGE, $\mathrm{Cu}$ ) and incompatible elements (REE, $\mathrm{Zr}, \mathrm{Y}, \mathrm{Rb}, \mathrm{Ba}, \mathrm{K}_{2} \mathrm{O}, \mathrm{Na}_{2} \mathrm{O}$ ) than $\mathrm{M}_{\mathrm{U}}$, but higher $\mathrm{MgO}, \mathrm{C}$, and LOI.

\section{Drill core profiles}

In the following section, we discuss in detail four drill cores that represent typical stratigraphic variants (UMT 263, 341d1, 378, and 449) (Fig. 4).

Drill core UMT 263 is located in Zone 1 (i.e., the relatively shallow northern portion of the property, see Fig. 1 of Maier et al. (2020)). The hanging wall sequence above the Bastard Reef (BAR) consists of interlayered pyroxenite, gabbro, and anorthosite. In this specific drill core, the hanging wall is unusually thick $(\sim 70 \mathrm{~m})$ and contains relatively high PGE contents (frequently 10 to $100 \mathrm{~s}$ of ppb, occasionally up to $1 \mathrm{ppm}$ ), whereas most other hanging wall intervals of the Bastard Reef are PGE poor. Possibly, the interval represents a faulted block of rocks originally located below the Bastard Reef. This interpretation is consistent with the abundance of granite veins in this interval, likely along subsidiary fractures. The Bastard Reef consists of a $\sim 5$-m sulfide-bearing pyroxenite, overlying interlayered gabbro and anorthosite of the Middling unit with a sharp contact. M2 is represented by a thin $(0.6 \mathrm{~m})$ sulfidic pyroxenite. This is underlain by pegmatoidal harzburgite of $\mathrm{M} 1_{\mathrm{L}}$, pegmatoidal orthopyroxenite $\left(\mathrm{M} 1_{\mathrm{U}}\right)$, and then $30 \mathrm{~m}$ of heterogeneously textured norite that shows locally pegmatoidal texture, may be veined by felsic material and may contain enclaves or intrusives of fine-grained norite (e.g., at a depth of $888 \mathrm{~m}$ ). Below the norite is a further 20m layer of pegmatoidal harzburgite $\left(\mathrm{M} 1_{\mathrm{L}}\right)$, olivine pyroxenite, and, locally, pyroxenite containing abundant fesic veins and large (several centimetre-wide) sulfide pods. This is underlain (from $\sim 916 \mathrm{~m}$ ) by a heterogenous sequence of calcsilicate xenoliths within pegmatoidal norite. The borehole was terminated at $925.77 \mathrm{~m}$.

As expected, $\mathrm{MgO}$ contents are relatively high in the harzburgites of $\mathrm{M} 1_{\mathrm{L}}$, but lower in orthopyroxenite of $\mathrm{M} 1_{\mathrm{U}}$ and norite. Interestingly, both $\mathrm{M} 1_{\mathrm{L}}$ layers show a broad trend of upward increasing $\mathrm{MgO}$ content, analogous to the observation of Yudovskaya et al. $(2017 \mathrm{a}, \mathrm{b})$ in drill core UMT314. The harzburgites have relatively low $\mathrm{Cr} /$ $\mathrm{MgO}(0-50)$ due to the predominance of olivine, whereas pyroxenites have higher $\mathrm{Cr} / \mathrm{MgO}$ of 80 to $>200$, with the highest values reflecting the presence of chromite. All rocks of the reef interval (i.e. BAR, M2, M1) contain elevated PGE, at $>400 \mathrm{ppb}$. There is a broad general trend of a downward decrease in PGE through the profile, an observation that has been made across much of the Turfspruit project area. PGE contents are particularly high in M2 and M1, but in addition, levels are also elevated in the noritic pegmatoid between the M1 layers, notably in some large pods of sulfide. $\mathrm{Pt} / \mathrm{Pd}$ is mostly around unity, but sharply higher in M2 and the Middling unit, a trend that is found across the project area. $\mathrm{Au} / \mathrm{Pd}$ broadly mirrors the $\mathrm{Pt} / \mathrm{Pd}$ trend. $\mathrm{Ca} / \mathrm{Al}_{2} \mathrm{O}_{3}$ is mostly $0.5-1$, overlapping with typically magmatic values found in the UCZ of the WBC. However, higher, putatively non-magmatic values of $\mathrm{Ca}$ / 

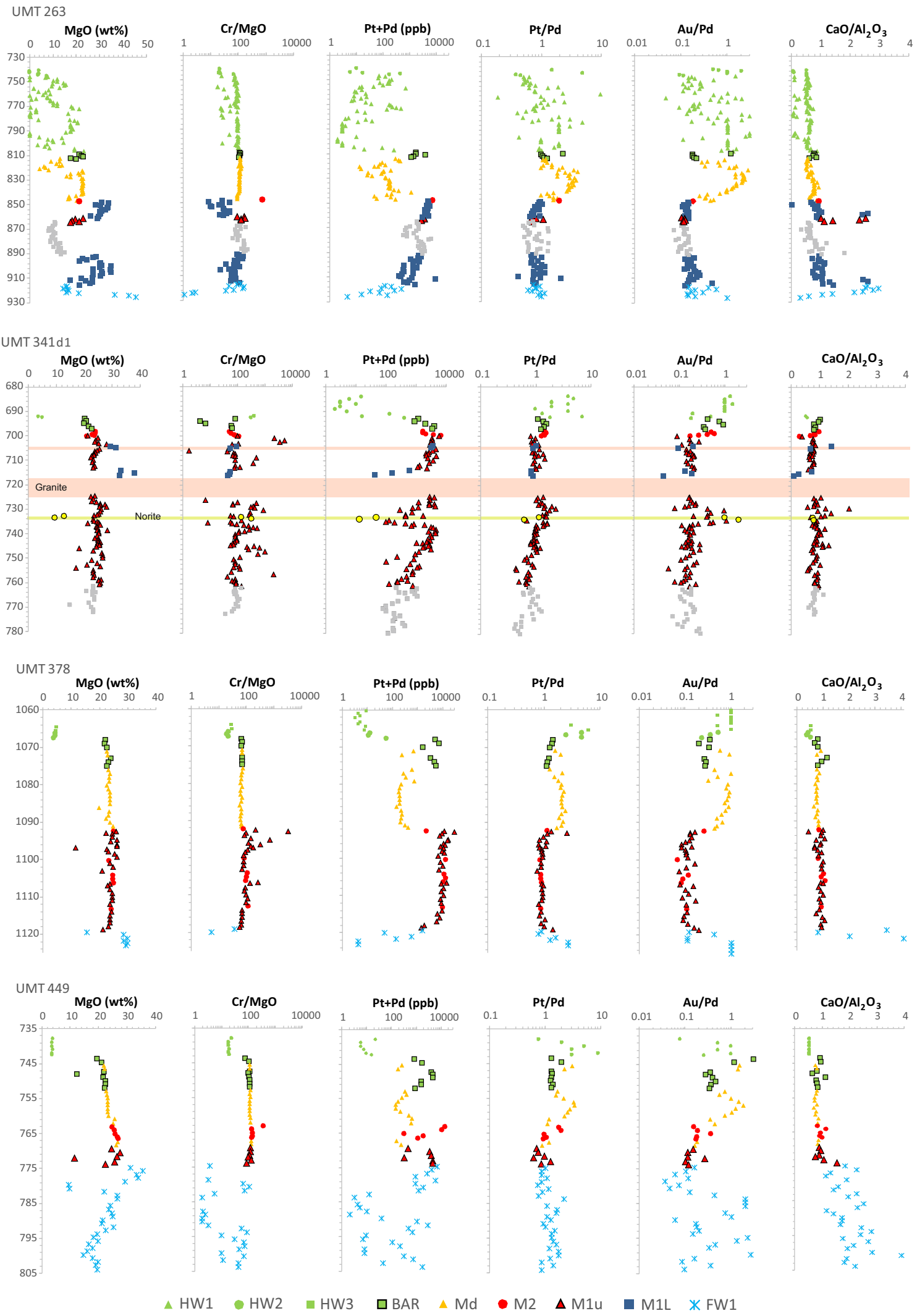

Fig. 4 Compositional variation of selected major and trace element concentrations as well as element ratios in representative drill cores intersecting the Flatreef 
$\mathrm{Al}_{2} \mathrm{O}_{3}$ are found in $\mathrm{M}_{\mathrm{U}}$, as well as some of the relatively more pyroxene-rich portions of $\mathrm{M} 1_{\mathrm{L}}$ and in the footwall parapyroxenites.

Drillcore UMT341d1 intersected a thick pyroxenitic reef interval, from the Bastard Reef into the footwall of M1, with only thin intervals of olivine-rich rocks. The hanging wall of BAR consists of mottled anorthosite that has a sharp basal contact to sulfide-bearing BAR pyroxenite, which in turn directly overlies M2. The boundary between BAR and M2 is marked by a 2-3$\mathrm{m}$ relatively PGE depleted pyroxenitic interval. $\mathrm{M} 2$ is underlain by nearly $60 \mathrm{~m}$ of predominantly pegmatoidal orthopyroxenite classified as $\mathrm{M}_{\mathrm{U}}$. There is a $50-\mathrm{cm}$ granite vein in the upper portion of $\mathrm{M}_{\mathrm{U}}$, and a 7-m granite interval at around mid-level. Both granite veins have harzburgite in their footwall and/or hanging wall (Electronic Supplementary Materials (ESM) Fig. $1 \mathrm{a}-\mathrm{b})$. There is also a 1.2- $\mathrm{m}$ fine- to medium-grained norite in the central portion of $\mathrm{M}_{\mathrm{U}}$ that has sharp contacts to the pyroxenite host rock (ESM Fig. 1c). The base of $\mathrm{M}_{\mathrm{U}}$, i.e. the contact to the footwall pyroxenite, is defined purely on textural grounds, by a change from pegmatoidal to medium-grained pyroxenite. In compositional terms, there is no clear break between these two lithologies.

While $\mathrm{MgO}$ contents of the rocks fall into a relatively narrow range of $20-25 \%, \mathrm{Cr} / \mathrm{MgO}$ ratios show more variation than in many other drill cores, due to many samples being enriched in chromite, in the form of thin schlieren, lenses, or stringers, as well as small irregular blebs. Notably, the chromite is commonly set in a matrix of plagioclase, in common with many other Flatreef drill cores. As in drill core UMT263, PGE contents show a broad trend of progressive downward decrease. In addition, PGE contents sharply decrease at a level a few metres above and below the main granite intrusive and around the norite layer/enclave. As in most other Flatreef cores (with the exception of drill core UMT263), Pt/Pd ratios decrease with depth. M1 has markedly lower Pt/Pd (around unity) than $\mathrm{M} 2$ and other hanging wall rocks $(>1) . \mathrm{Au} / \mathrm{Pd}$ again broadly mirrors the $\mathrm{Pt} / \mathrm{Pd}$ trend. $\mathrm{CaO} / \mathrm{Al}_{2} \mathrm{O}_{3}$ is relatively homogenous at around $0.5-1$ suggesting relatively little input of the country rocks. Sulfide contents are mostly $1-4 \%$, with a few samples containing up to $8 \%$ sulfide. The lowest sulfide contents $(<0.5 \%)$ are found in the norite and its hostrocks.

Bore hole UMT378 was collared in Zone 1, approximately $1 \mathrm{~km}$ to the NW of bore hole UMT263. At the top of the CZ are $\sim 5 \mathrm{~m}$ of mottled anorthosite (HW1-2). The rocks of the Flatreef show much less lithological variation than in many other drill cores, reflected by a near constant $\mathrm{MgO}$ content of 20-24\% across BAR, M2, and M1. The Bastard Reef consists of 2 sulfidic layers separated by a barren pyroxenite, reminiscent of the apophyses commonly developed below the Merensky Reef in the WBC (Chistyakova et al. 2019). M2 consists of a thin horizon of moderate PGE enrichment overlying thick $\mathrm{M} 1_{\mathrm{U}}$ pegmatoidal pyroxenite reef. Notably, within the central portion of $\mathrm{M}_{\mathrm{U}}$, there are several, metre-wide, medium grained M2 intervals, as well as 2-m-wide intervals of olivine pyroxenite. The $\mathrm{M} 1_{\mathrm{U}}$ reef interval directly overlies $>40 \mathrm{~m}$ of predominantly calcsilicate. At the top of the calcsilicate is a fine-grained contact rock, $0.5 \mathrm{~m}$ in width, that is strongly calcite veined. The bore hole was terminated in the calcsilicate, and thus it is unclear whether the calcsilicate represents a xenolith or the sedimentary floor of the intrusion.

In the igneous rocks, $\mathrm{Cr} / \mathrm{MgO}$ is mostly just below 100 , except for a few samples containing $\mathrm{Cr}$ stringers located in the upper portion of $\mathrm{M}_{\mathrm{U}}$ where $\mathrm{Cr} / \mathrm{MgO}$ is relatively high. In contrast, in the calcsilicates, $\mathrm{Cr} / \mathrm{MgO}$ is extremely low $(<$ 10). PGE contents are $>100 \mathrm{ppb}$ in all pyroxenites and olivine pyroxenites. Particularly high PGE contents occur in M2 and throughout much of $\mathrm{M} 1_{\mathrm{U}}$. Within the latter, PGE contents show a progressive downward decrease that becomes more pronounced in the basal $2 \mathrm{~m}$ of $\mathrm{M}_{\mathrm{U}}$ and into the $\mathrm{FW}$ calcsilicate even though PGE contents are still between 100 and $1000 \mathrm{ppb}$ in the uppermost $3 \mathrm{~m}$ of the calcsilicate. $\mathrm{Pt} / \mathrm{Pd}$ is slightly above unity in $\mathrm{M} 2$, but mostly $<1$ in $\mathrm{M} 1_{\mathrm{U}}$. In the calcsilicate, $\mathrm{Pt} / \mathrm{Pd}$ increases to values greater than unity. $\mathrm{Ca} /$ $\mathrm{Al}$ is mostly just below or around unity, except in the calcsilicate where $\mathrm{Ca} / \mathrm{Al}$ levels reach 4 .

Drill core UMT449 is also derived from Zone 1, from a hole that was drilled between bore holes UMT378 and UMT263. The HW unit consists of $\sim 5 \mathrm{~m}$ of leuconorite and mottled anorthosite, underlain by two mineralised pyroxenite intervals separated by a barren pyroxenite that are interpreted as the Bastard Reef and its footwall apophyse. M2 forms a $\sim 5$-m layer within medium grained Middling pyroxenite. $\mathrm{M}_{\mathrm{U}}$ is about $4 \mathrm{~m}$ thick, directly overlying at least $30 \mathrm{~m}$ of calcsilicate before the hole was terminated.

In the magmatic rocks, $\mathrm{Cr} / \mathrm{MgO}$ is mostly $100-120$, except for a much higher value (>300) in the uppermost sample of M2, likely due to the presence of a Cr stringer, and variably low values $(\ll 100)$ in the calcsilicate. PGE contents are between 100 and $800 \mathrm{ppb}$ throughout the Middling unit, but reach up to $>10 \mathrm{ppm}$ in M2, and are highly variable (200 $4000 \mathrm{ppb}$ ) in $\mathrm{M} 1_{\mathrm{U}}$, the low values reflecting the presence of barren albitic veins. The calcsilicate also has locally highly elevated PGE contents ( $>1 \mathrm{ppm})$. $\mathrm{Pt} / \mathrm{Pd}$ is at or above unity in M2 and the Middling unit, and slightly lower in much of $\mathrm{M} 1_{\mathrm{U}}$. Several of the calcsilicate samples have strongly elevated $\mathrm{Cu} / \mathrm{Ni}$ (not shown), reflecting the presence of relatively $\mathrm{Cu}$ rich sulfides. $\mathrm{CaO} / \mathrm{Al}_{2} \mathrm{O}_{3}$ is mostly $0.6-1$, but with somewhat higher values (up to 1.5 ) in the basal sample of $\mathrm{M}_{\mathrm{U}}$ and, particularly, the calcsilicate.

In summary, the drill core data show that the examined portion of the Flatreef shares a number of similarities, but also important differences with the interval between the Merensky and Bastard reefs of the WBC. Key similarities include (i) the presence of $\mathrm{Cr}$ stringers bounding/underlying the reefs, (ii) the common occurrence of pegmatoid and harzburgite at the base of the reefs, and (iii) the presence of elevated PGE contents in 
the footwall of the reefs. Key differences include (i) the much greater thickness of footwall mineralisation in the Flatreef (up to $10 \mathrm{~s}$ of metres e.g. in UMT263) relative to the Merensky Reef of the WBC (a few centimetres to rarely a few metres; Barnes and Maier 2002). (ii) The development of several mineralised layers within poorly mineralised pyroxenite and norite in the Flatreef, whereas the Merensky and Bastard reefs in the WBC normally form just 1 layer each. (iii) The occurrence, in the Flatreef, of harzburgite $\left(\mathrm{M} 1_{\mathrm{L}}\right)$ below, within and above orthopyroxenite $\left(\mathrm{M}_{\mathrm{U}}\right)$, whereas in the MR of the WBC, harzburgite, where developed, always underlies pyroxenite (Viljoen 1999). (iv) The enhanced thickness of Flatreef (M1) pegmatoid (up to $60 \mathrm{~s}$ of metres in UMT341d) compared with the Merensky pegmatoid in the WBC ( 2 m maximum). (v) Whereas the MR of the WBC typically rests several kilometres above the sedimentary country rocks, the highgrade reefs of the Flatreef (M1 and M2) can rest directly on calcsilicate floor rocks (e.g. in UMT263, UMT378, UMT449). (vi) $\mathrm{Pt} / \mathrm{Pd}$ in the Flatreef and its floor rocks progressively decrease with depth, whereas in the MR of the $\mathrm{WBC}$ and its floor rocks $\mathrm{Pt} / \mathrm{Pd}$ remains largely constant (Maier et al. 2013).

\section{Thickness variation of Flatreef units}

In Fig. 5, we have compiled contour maps of the thickness of certain key units across the project area. Of particular note is that $\mathrm{BCU}, \mathrm{M} 1_{\mathrm{U}}$, and $\mathrm{M} 1_{\mathrm{L}}$ show complimentary thickness variation, i.e., where $\mathrm{BCU}$ is thick, the combined $\mathrm{M} 1$ package is thin, and where $\mathrm{M} 1_{\mathrm{U}}$ is thick, $\mathrm{M} 1_{\mathrm{L}}$ is thin, and vice versa. In addition, the thicknesses of the M1 units appear to be controlled, at least in part, by the changes in dip of the sequence, with enhanced thickness occurring where dip flattens (Fig. 6).

\section{Binary variation diagrams}

Binary plots of PGE vs. wt $\%$ sulfide show well-defined correlations between $\mathrm{Cu}$ and $\mathrm{Ni}$ with sulfide, and somewhat weaker correlations between PGE, Au, and Co with sulfide (Fig. 7). The positive correlations likely reflect control of metals by sulfide, but individual reefs define distinct trends. The UG2 reef shows the lowest $\mathrm{Pt} /$ sulfide and $\mathrm{Pd} /$ sulfide ratios of the analysed rocks, followed by $\mathrm{M} 1_{\mathrm{L}}$ and the Bastard Reef, and with $\mathrm{M} 1_{\mathrm{U}}$ and M2 having the highest PGE/S ratios. The Bastard Reef is relatively rich in $\mathrm{Au}$, whereas $\mathrm{M}_{\mathrm{L}}$ is relatively rich in $\mathrm{Ni}$ and $\mathrm{Co}$. In terms of $\mathrm{Cu} / \mathrm{S}$, all units show considerable overlap.

When Pt and Pd are plotted against each other (Fig. 8a), mostly good positive correlations are evident, but with subtle differences for individual units. The Middling and HW units are strongly Pt enriched, BAR and M2 are slightly Pt enriched, whereas M1, UG2, and the FW rocks are variably Pd enriched. Significant scatter is confined to the HW and FW rocks of the reefs. The average $\mathrm{Pt} / \mathrm{Pd}$ of $\mathrm{M} 2$ is higher than that of the MR in the WBC (Table 1).

The correlation between $\mathrm{Pd}$ and $\mathrm{Cu}$ is relatively poor (Fig. 8 b). Most samples have $\mathrm{Cu} / \mathrm{Pd}$ significantly below primitive mantle ( 7000; Barnes and Maier 1999), with $\mathrm{M} 2$ and $\mathrm{M} 1_{\mathrm{U}}$ having the lowest $\mathrm{Cu} / \mathrm{Pd}, \mathrm{M}_{\mathrm{L}}, \mathrm{UG} 2$ and the Bastard Reef having slightly higher $\mathrm{Cu} / \mathrm{Pd}$, whereas several samples from the Middling, HW and FW units (as well as several Bastard Reef samples) have $\mathrm{Cu} / \mathrm{Pd}$ at or above PM.

Nickel (Fig. 8c) shows generally good positive correlations with $\mathrm{Cu}$. Compositional overlap between units is strong, but
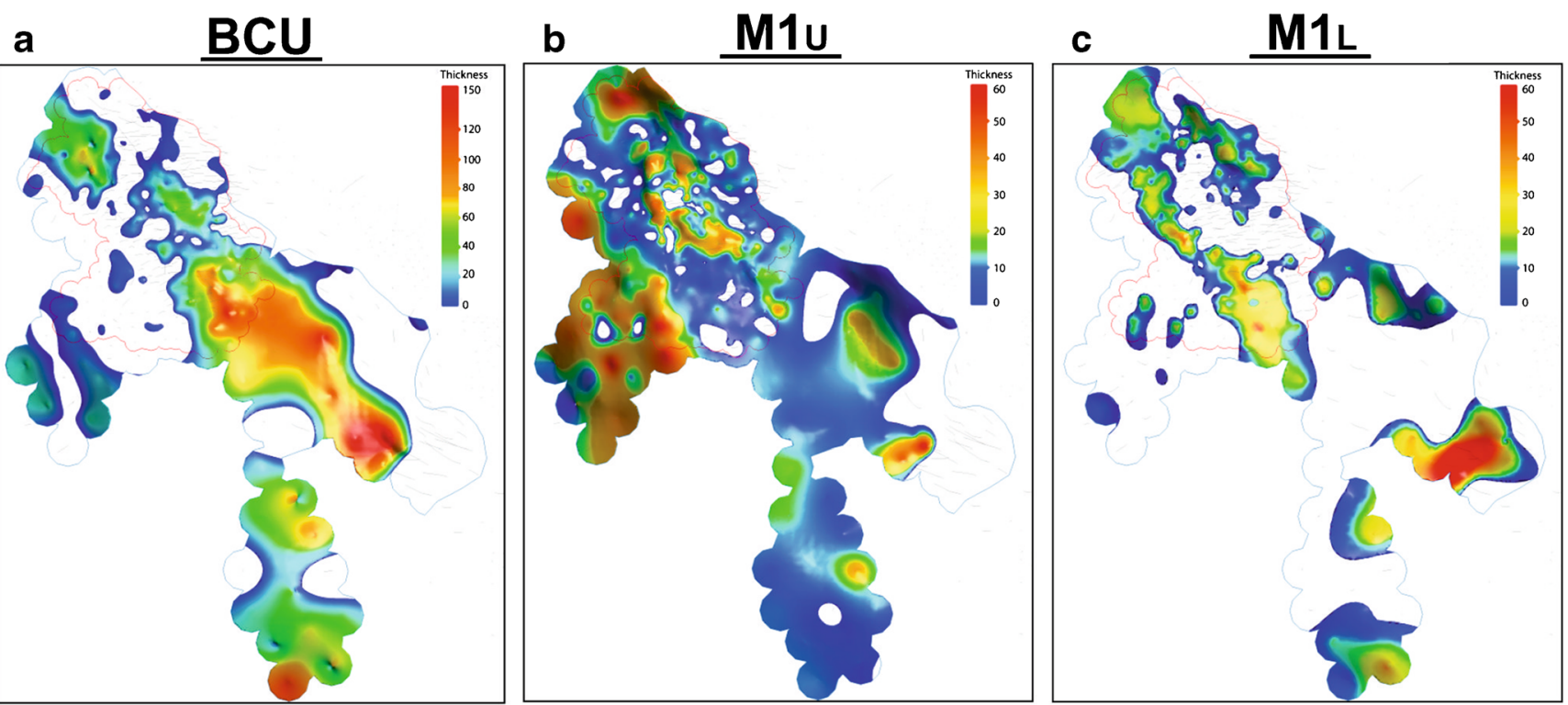

Fig. 5 Diagram showing thickness variation of a Bastard, $\mathbf{b ~ M} 1_{\mathrm{U}}$, and $\mathbf{c} \mathrm{M} 1_{\mathrm{L}}$ layers across the Platreef project area (modified from Peters et al. 2016) 


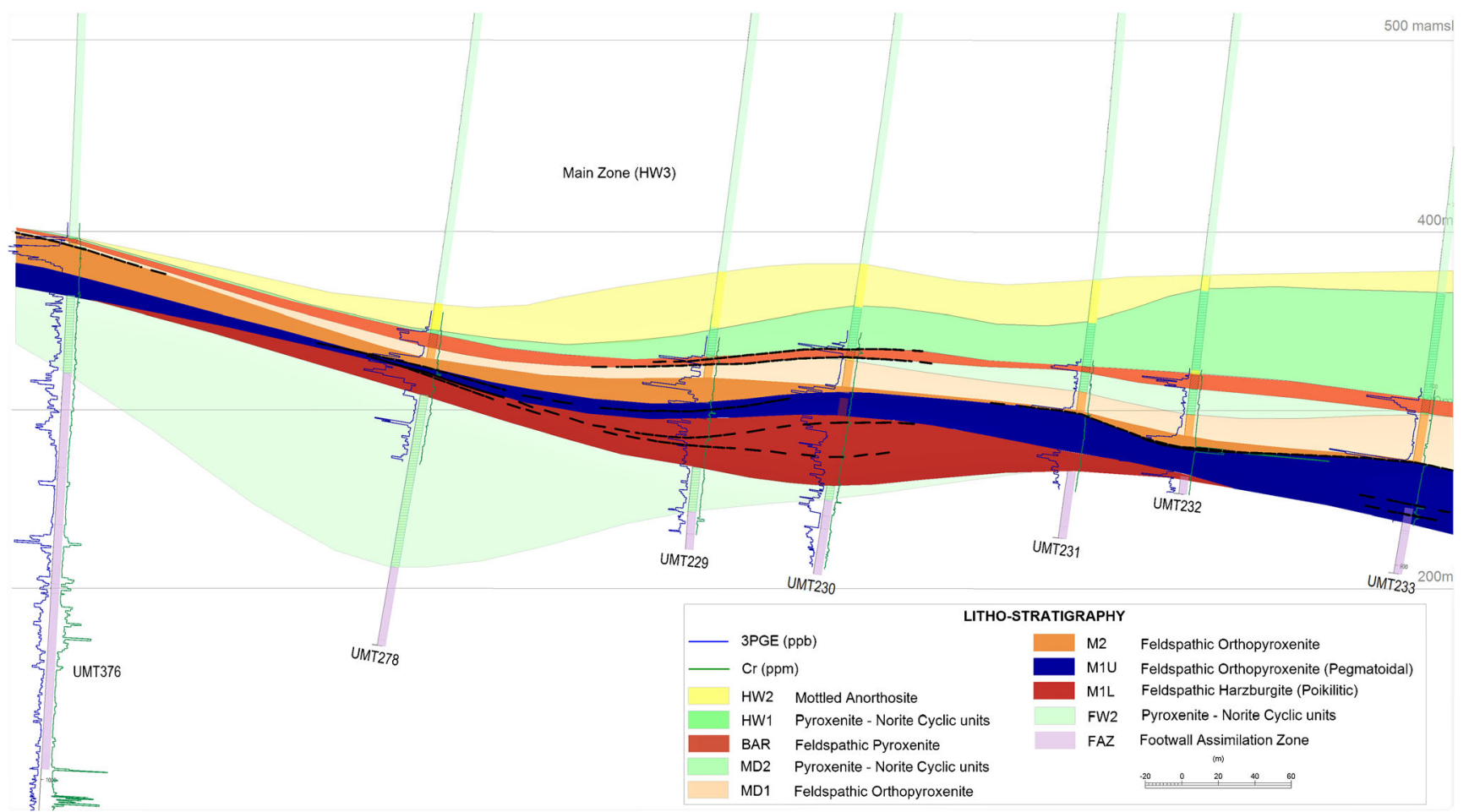

Fig. 6 Vertical section through the Flatreef displaying lateral thickness and facies variations

the UG2 and FW rocks tend to have somewhat higher $\mathrm{Cu} / \mathrm{Ni}$ ratios than the remainder of the samples.

Pd shows a good positive correlation with Ir (Fig. 8d), but $\mathrm{Au} / \mathrm{Pd}$ is highly variable, showing relatively low values in the $\mathrm{UG} 2$, FW, M1 and M2, but higher values in samples from the Middling unit, HW and BAR (Fig. 8e). These trends are essentially mirroring variation in $\mathrm{Pt} / \mathrm{Pd}$. Figure $8 \mathrm{f}$ illustrates that most Flatreef units have broadly similar Pt/Ir as the Merensky Reef of the western Bushveld, but strongly elevated Pd/Ir. Both ratios are somewhat lower than in most Platreef rocks (not shown). BAR has systematically higher Pt/Ir than the other units, whereas the UG2 has the lowest Pt/Ir and Pd/Ir.

\section{Discussion: petrogenesis of the Flatreef}

\section{Composition and emplacement of the Flatreef parent magmas: constraints from $\mathrm{Cu}$ contents}

If the Flatreef is the stratigraphic correlative of the uppermost UCZ in the WBC (Grobler et al. 2019), then it would seem reasonable to propose that the parent magma to the Flatreef was a mixture of Bushveld B1 and B2 magmas, as has been modelled for the Merensky Reef of the WBC (Barnes and Maier 2002). However, the Flatreef rocks are too $\mathrm{Cu}$ rich to be explained solely by any mixture between B1 and B2 magmas (Fig. 9). The data are equally inconsistent with crystallisation from relatively more fractionated (i.e. enriched in $\mathrm{Cu}$ and depleted in Ir) B1 or B2 magmas than those in the rest of the Bushveld because Flatreef pyroxene, plagioclase, and olivine have broadly similar compositions to those in the uppermost $\mathrm{CZ}$ rocks elsewhere (Abernethy et al. 2020).

One could propose that the high $\mathrm{Cu}$ contents in the Flatreef are due to in situ sulfide melt fractionation after magma emplacement, but this model is rejected in view of the lack of a complementary component of monosulfide solid solution (MSS) in the Flatreef. Alternatively, Cu-rich magmatic sulfide could have been assimilated prior to final emplacement, in a staging chamber, followed by entrainment of the sulfides during continued ascent of the magma (Lee 1996; McDonald and Holwell 2007). This model could potentially explain the vastly larger PGE budget of the Flatreef, and indeed the entire northern limb, compared with the UCZ in the WBC; However, conclusive evidence for sulfide melt saturation of Bushveld magmas prior to final emplacement is not documented. For example, McDonald and Holwell et al. (2007) argued that signatures of metal depletion in some northern lobe $\mathrm{LZ}$ rocks reflect sulfide melt saturation prior to emplacement of the LZ, but undepleted LZ sequences also exist (Yudovskaya et al. 2013). Holwell et al. (2011) found sulfide inclusions in Platreef chromite crystals and interpreted both to have been entrained from depth. Our main objection to the sulfide entrainment model is that the fine-grained marginal rocks of the Bushveld Complex, which are generally accepted to represent the parent liquids to the intrusion, are undersaturated in sulfide melt (Barnes et al. 2010). Also, most global 
Fig. 7 Binary variation diagrams of chalcophile metals vs sulfide. Data represent $>2000$ analyses from 20 drill cores (for locations see Fig. 1 in Maier et al. (2020)). a $\mathrm{Pd}, \mathbf{b} \mathrm{Pt}, \mathbf{c ~ I r}, \mathbf{d ~ R h}, \mathbf{e ~ A u}, \mathbf{f} \mathrm{Cu}, \mathbf{g}$ $\mathrm{Ni}, \mathbf{h}$ Co.

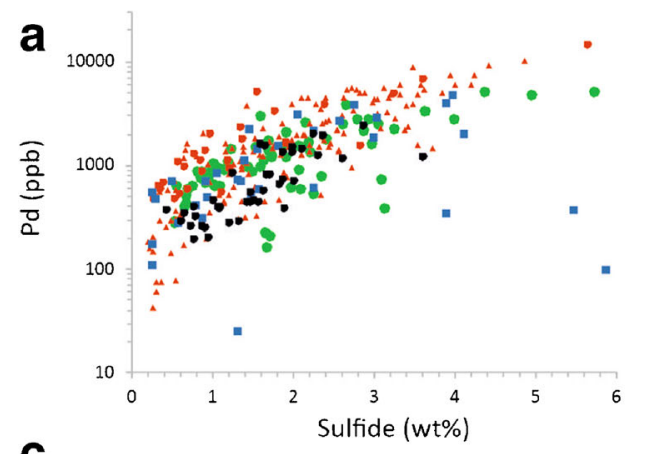

C

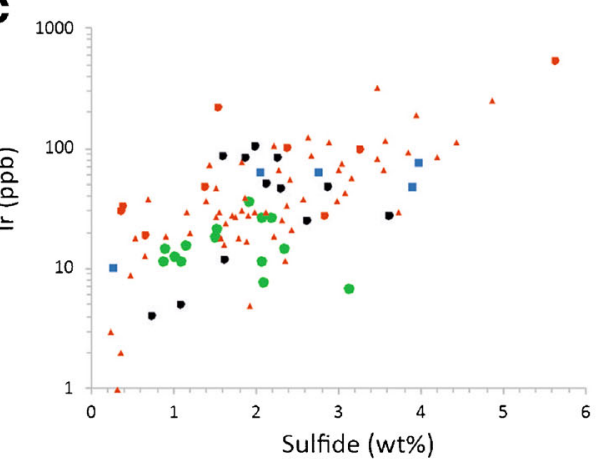

e

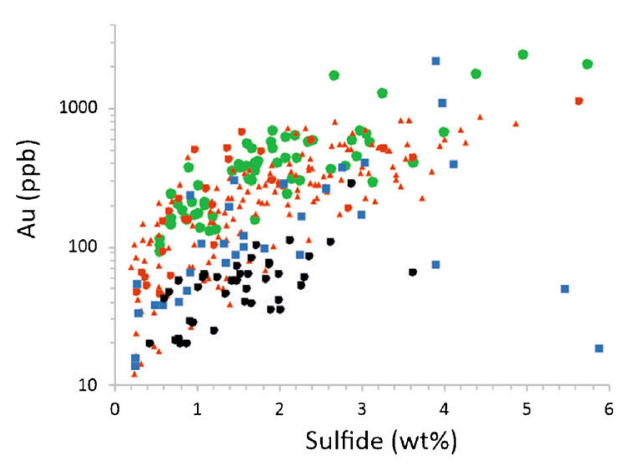

9

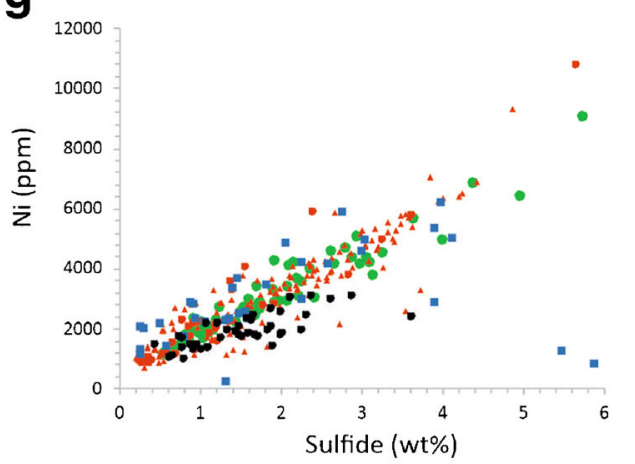

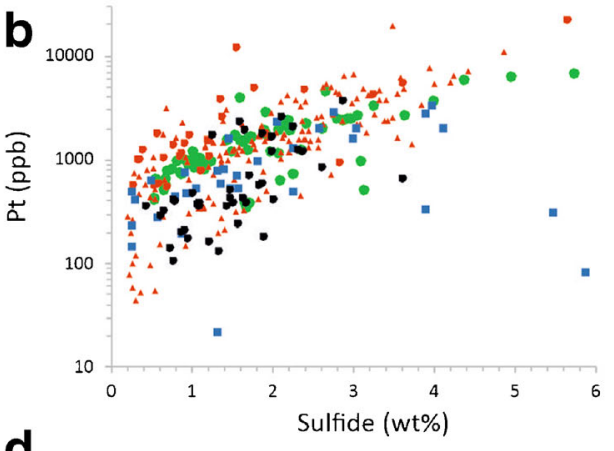

d

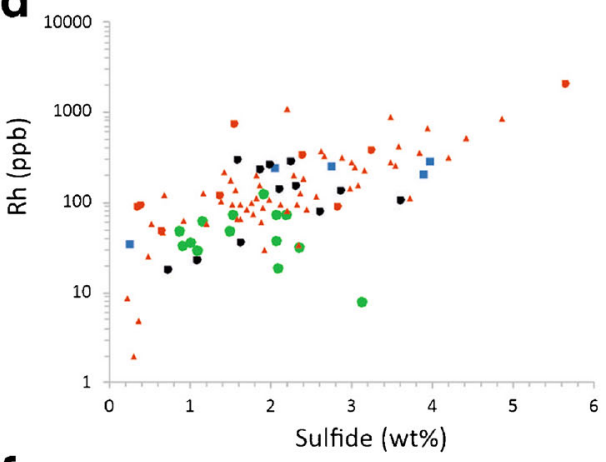

f

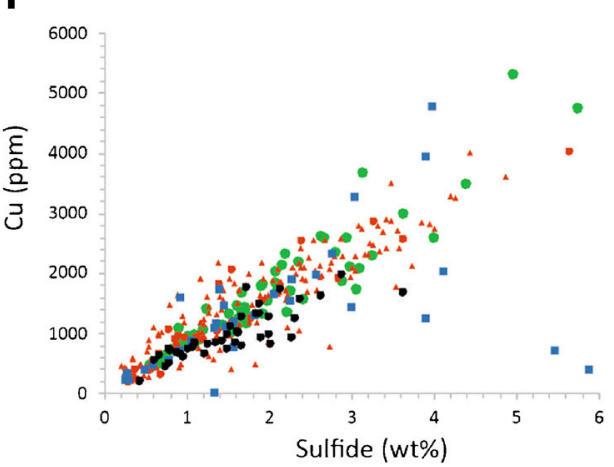

h

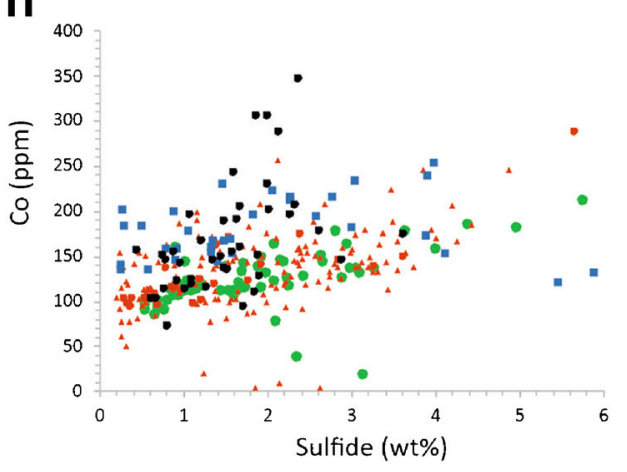

- Bar - M2 a M1u - M1L UG2

PGE reefs are situated near the transition from ultramafic to mafic rocks (Maier et al. 2015), suggesting that in situ fractionation plays a dominant role in reef formation.

A more plausible model for the relative $\mathrm{Cu}$ enrichment of the Flatreef is addition of country rock $\mathrm{Cu}$ to the mixed B1/B2 parent magma. The shales of the Duitschland and Malmani formations have average contents of 20-25 ppm and $40 \mathrm{ppm}$ $\mathrm{Cu}$, respectively (Baglow and Brandl 2009). In contrast, dolomite of the Malmani Formation has $<5 \mathrm{ppm} \mathrm{Cu}$ and is thus unlikely to be an important source of external $\mathrm{Cu}$. Bearing in 
Fig. 8 Binary variation plots of chalcophile metals. Data source as in Fig. 7. a Pd vs Pt, b Pd vs $\mathrm{Cu}, \mathbf{c} \mathrm{Ni}$ vs $\mathrm{Cu}, \mathbf{d} \mathrm{Pd}$ vs Ir, e $\mathrm{Au} /$ $\mathrm{Pd}$ vs $\mathrm{Pt} / \mathrm{Pd}$, f Pt/Ir vs Pd/Ir
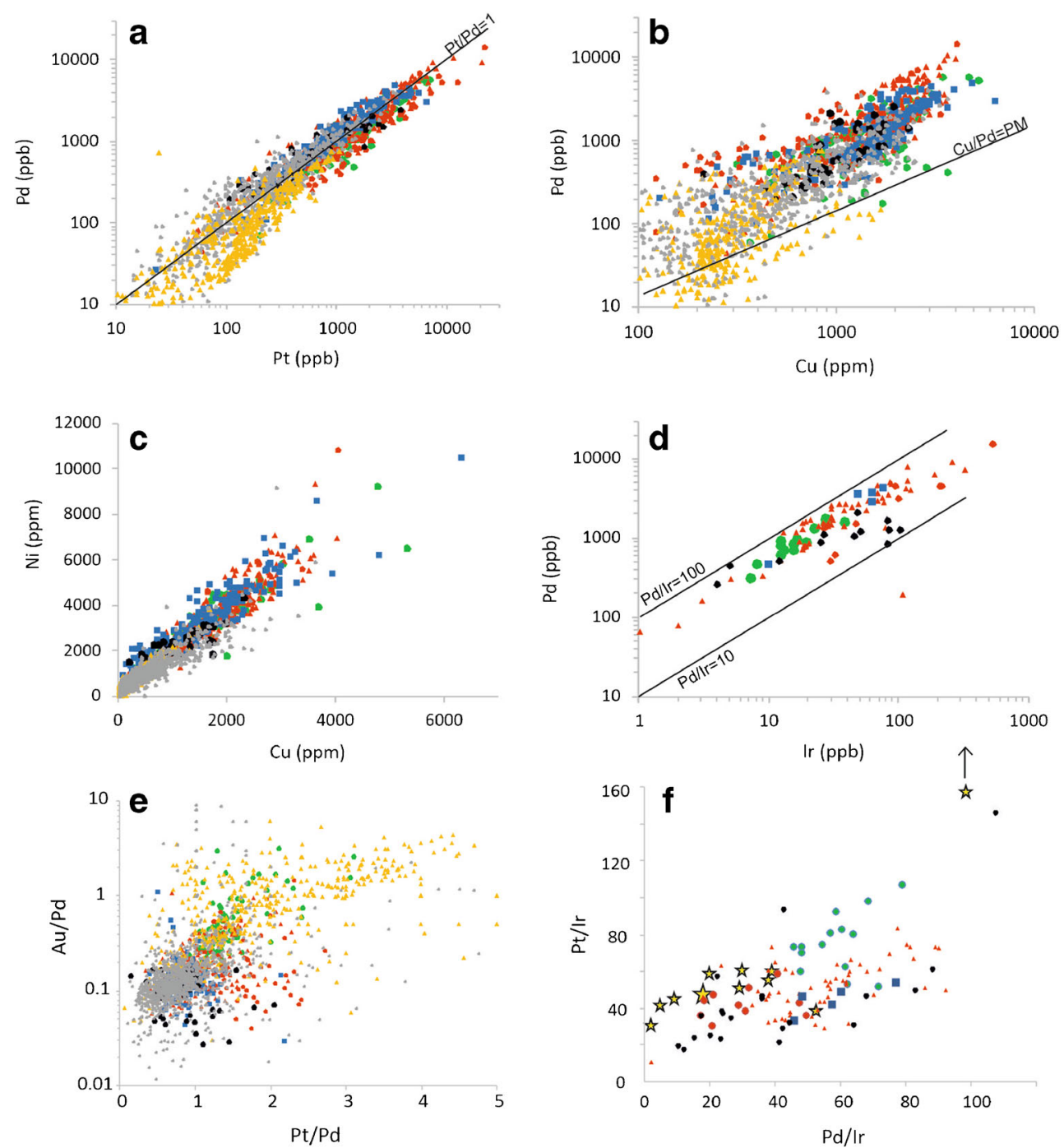

$\triangle$ Midd+HW - Bar - M2 $\triangle \mathrm{M} 1 \mathrm{u}=\mathrm{M} 1 \mathrm{~L} \cdot \mathrm{UG2}$ - FW therensky R. WBC mind that significant in situ assimilation of bulk crust or partial melts of crust is inconsistent with the overlap in silicate mineral composition between the Flatreef and the UCZ elsewhere in the Bushveld (Abernethy et al. 2020), $\mathrm{Cu}$ (and S) were likely introduced selectively, i.e., by a fluid that dissolved country rock sulfides.

\section{Hydrodynamic cumulate sorting and sieving during granular flow}

Maier et al. (2013) applied a model of crustal loading and subsidence, previously proposed for certain sedimentary basins (Howell and van der Pluijm 1999) to the Bushveld magma chamber. The model is consistent with the lopolithic shape of the Bushveld and many other layered intrusions. The authors further proposed that seismicity associated with subsidence, notably preceding the emplacement of the voluminous Main Zone magma pulse(s), mobilised incompletely consolidated crystal slurries at the top of the Critical Zone crystal pile and caused down-dip slumping of the slurries towards the centre of the Bushveld lopolith. The slurries underwent phase sorting through kinetic sieving resulting in layering, with pyroxenes (+chromite and sulfide) concentrated near the base of flows, and feldspathic cumulates deposited in the upper portion of flows. Apophyses of the UG1 chromitite and the Merensky Reef (Maier and Barnes 2008; Latypov et al. 2017; Mitchell et al. 2019) and exposures of anorthosite seams at Maandagshoek (Maier et al. 2016b) suggest that crystal slurries locally injected into their floor and roof cumulates. The slurry model was tested experimentally by Forien et al. (2015) and is consistent with microstructural studies that show abundant supra-solidus deformation textures 


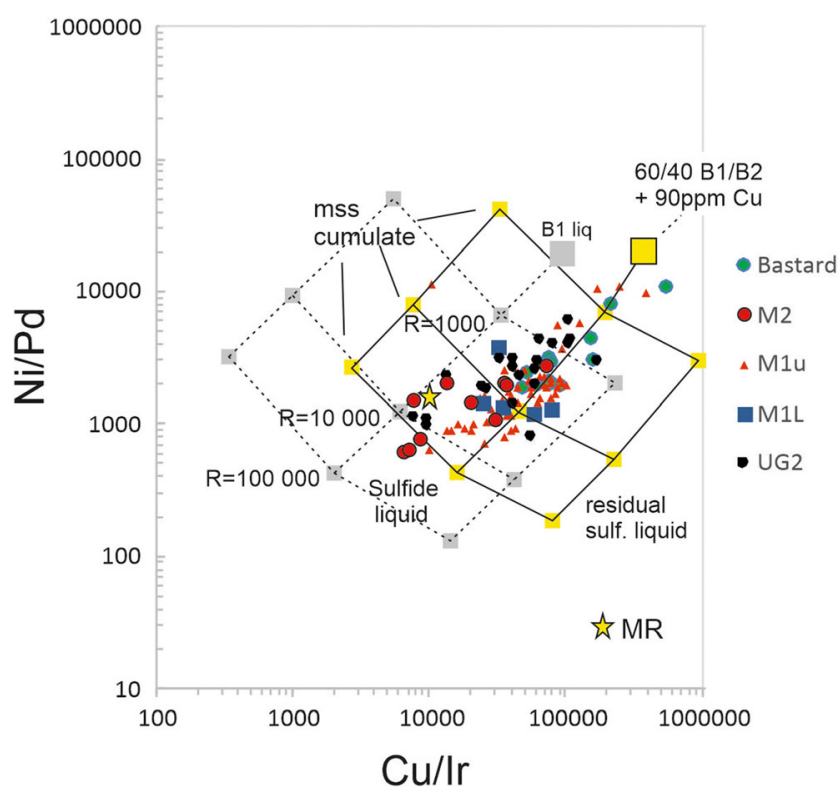

Fig. 9 Ratio diagram of $\mathrm{Ni} / \mathrm{Pd}$ vs $\mathrm{Cu} / \mathrm{Ir}$ for key reef intervals in drill cores UMT 314, 336, 341D, 345, 378, and 390. Modelling assumes MSS fractionation of a sulfide melt that segregated from Bushveld B1 magma and a 60:40 mixture of B1 and B2 magma at various $\mathrm{R}$ factors. Assumed sulfide melt/silicate melt $D$ values for Pd and Ir are 30,000, for $\mathrm{Cu}$ 1000, and for Ni 500. Assumed MSS/sulfide melt D values for Ir is 2.53, Pd 0.15, Cu 0.22, and Ni 1.37 (Barnes et al. 1997). Note that the data trend cannot be explained by a parent magma of B1 composition, but requires addition of significant $\mathrm{Cu}$ (in our case $90 \mathrm{ppm}$ )

interpreted to indicate deformation of a crystal-rich mush undergoing shear (Vukmanovic et al. 2018, 2019). Other features in layered intrusions that are consistent with slurry flow include structures interpreted as cross bedding and soft sediment deformation (Irvine et al. 1998), and the thickening of layers in potholes (Maier et al. 2013).

Grobler et al. (2019) presented drill core evidence in support of hydrodynamic processes in the Flatreef, including slump structures at various scales (centimetres to 100 s of metres), schlieren banding and flow structures, notably in the UG2 chromitite. We highlight here thickened intervals of mineralised pyroxenite that show little evidence of fractionation, as reflected by nearly constant $\mathrm{MgO}$ contents and $\mathrm{Cr} / \mathrm{V}$ ratios across up to $80 \mathrm{~m}$ of depth (Fig. 4). We suggest that the thickened intervals formed through accumulation of pyroxenitic crystal mushes in flow dynamic traps, essentially representing large potholes. Other features of the Flatreef consistent with efficient hydrodynamic processes include the relatively low plagioclase contents of Flatreef ultramafic rocks compared with those of the UCZ in the WBC, as well as apophyses of M2 in M1, and of M1 in its footwall (Fig. 4).

Volatiles may also play an important role in hydrodynamic sorting. The solubility of water in basaltic magma is strongly pressure dependent. Thus, in shallow magma chambers such as the Bushveld, emplaced at a depth of 1-3 km (Cawthorn and Davies 1983; Wallmach et al. 1989), it is likely that much of the dissolved $\mathrm{H}_{2} \mathrm{O}$ in the magma exsolved during intrusion. In the case of magma batches that intruded as sills into a largely consolidated cumulate pile, volatiles could be temporarily trapped, to be released by earthquakes associated with magma emplacement, together with $\mathrm{CO}_{2}$ and $\mathrm{H}_{2} \mathrm{O}$ formed during devolatisation of, and temporarily trapped within, dolomitic country rocks. In flowing magmas, particularly relatively viscous crystal mushes, gas bubbles may deform and coalesce and act as lubrication planes to substantially decrease the viscosity of the mush (Lesher and Spera 2015). This may facilitate slumping of crystal mushes or wholesale sliding and thrust duplication of semi-consolidated cumulate packages (see Appendix 5 in Grobler et al. (2019)), with the trapped fluids that acted as lubrication planes at the base of the thrust sheet ensuring the lithological integrity of the sheet (King Hubbert and Rubey 1959).

A further potential factor in facilitating crystal sorting could be grain size. Lai et al. (2017) have shown that finegrained layers can act as lubrication planes for granular flows. This model may be relevant in the case of $\mathrm{Cr}$ stringers that formed due to kinetic sieving along the base of ultramafic layers.

\section{Recrystallisation of the Flatreef}

Fluids or volatile-rich residual melts generated during cooling and crystallisation of cumulates or during metamorphism of footwall rocks may ascend through the crystal pile and locally remelt and recrystallise the rocks, notably at layer contacts (Bédard et al. 1988; Holness et al. 2006; Solano et al. 2014). These concepts were applied to explain the formation of the Merensky Reef by previous researchers (e.g. Ballhaus> and Stumpfl 1986; Boudreau 1988, 2008, 2016b; Boudreau and McCallum 1992; Nicholson and Mathez 1991; Mathez 1995; Mathez and Kinzler 2017). Specifically, it was proposed that ascending hydrous melts and volatiles were trapped at the contact between the Merensky pyroxenite and its footwall norite, both being incompletely solidified. The fluids/ hydrous melts lowered the solidus and liquidus temperatures of the rocks and caused an expansion of the olivine and chromite stability fields at the expense of pyroxene and plagioclase (Mathez and Kinzler 2017). In both layers, plagioclase and pyroxene underwent partial melting, the latter also peritectically reacting to olivine. In norite, some plagioclase was preserved, particularly if its proportion in the rock was initially supercotectic to form an anorthosite restite (Mathez and Kinzler 2017). The lower and upper contacts of the melt layer with the residual cumulates represent reaction fronts where chromitite stringers crystallised. Where some of the most volatile-rich melt was trapped, peritectic olivine reacted back to orthopyroxene to produce an orthopyroxenite pegmatoid, but where the volatile-rich residual melt escaped, harzburgitic pegmatoid was preserved. The composition of 
the proposed melts/fluids remains poorly constrained. In a fluid inclusion study of the Merensky Reef in the WBC, Zhitova et al. (2016) documented the presence of $\mathrm{CO}_{2}$ - and $\mathrm{CH}_{4}$-enriched fluids as well as brines.

The model of flux melting and recrystallisation has been highly controversial amongst Bushveld researchers. In part, this is because the cumulates contain few hydrous silicates. The most comprehensive documentation of the modal abundance of mica is that of Teigler and Eales (1996). They reported mostly $<1 \%$ phlogopite and hornblende in the LZ and lower portion of the CZ, albeit with many samples having several per cent mica. Similarly, Karykowski and Maier (2017) showed that the LZ can locally be highly enriched in phlogopite (up to 6 modal \%). Maier and Eales (1997) observed that within the UCZ, olivine-bearing cumulates tend to be relatively mica rich, and Maier (1995) reported abundant small $(<0.5 \mathrm{~mm})$ phlogopite from an olivine-bearing UCZ troctolite. These data suggest that the proportion of mica could have been underestimated in Bushveld cumulates. Also, Boudreau (2019) argued that vapour saturation may occur at a temperature beyond the stability of phlogopite, suggesting that scarcity of mica is not a reliable measure for the timing of vapour saturation in cumulates.

Another reason why the recrystallisation model remained controversial is that the Merensky pegmatoidal pyroxenite has been shown to have similar incompatible trace element contents and ratios to other, non-pegmatoidal pyroxenites in the UCZ (Barnes and Maier 2002). However, it could be argued that melt generated by fluid fluxing caused increased porosity that facilitated escape of the hydrous melt, thereby resulting in relatively low contents of mica and incompatible trace elements. Furthermore, Li et al. (2005) and Boudreau (2016a) reported that in the Merensky and J-M reefs, melt inclusions within chromite, olivine, and apatite are composed largely of biotite and Na-amphibole and lesser amounts of olivine and pyroxene. These alkaline inclusions may represent the residual/partial melt.

Cumulate recrystallisation triggered by volatile-rich melts or fluids would provide an explanation for several other observations in the Bushveld Complex and other layered intrusions, including (i) pervasive reversed zonation in plagioclase of the UCZ (Maier 1995; Maier and Eales 1997; Maier et al. 2016b; Hunt et al. 2018) and in the Stillwater Complex (Czamanske and Scheidle 1985; Boudreau 1988; Baker and Boudreau 2019), (ii) elevated $\mathrm{Sr}_{\mathrm{i}}$ ratios below and within certain ultramafic layers (UCZ chromitite-Kinnaird et al. 2002; UG2-Schannor et al. 2018), and (iii) the occurrence of LG6 chromitite with unusually high $\mathrm{Cr} / \mathrm{Fe}$ and hosted by unusually olivine-rich silicate rocks, in pothole-like depressions at the Ruighoek mine (Latypov et al. 2018) which we interpret to have resulted from channelised fluid flow triggering oxidation of $\mathrm{Fe}$ in chromite and recrystallisation of pyroxenite to harzburgite.
The recrystallisation model was first applied to the Platreef by de Waal (1977) and to the Flatreef by Marquis (2015) to explain, amongst other features, the pegmatoidal textures and abundance of olivine, notably in $\mathrm{M} 1_{\mathrm{L}}$. The model offers a possible explanation for the observed variation in relative thickness of orthopyroxenite and harzburgite across the property (Fig. 5)-where orthopyroxenite is thick, harzburgite is thin, and vice versa - in that both rock types could be reaction products of an originally medium-grained orthopyroxenitenorite interval. The model would potentially also provide an explanation for several other observations namely (i) the preferred occurrence of $\mathrm{M} 1_{\mathrm{L}}$ in areas where the dip of the sequence changes significantly which could be interpreted to favour early-stage trapping of fluids and volatile-rich melts percolating upwards along layer contacts (Fig. 6), (ii) the subtle depletion in incompatible trace elements in $\mathrm{M} 1_{\mathrm{L}}$ relative to $\mathrm{M} 1_{\mathrm{U}}$ (Table 1) that could reflect late-stage escape of residual volatile-rich melt thereby stabilising olivine, and (iii) the association of chromite with intercumulus plagioclase in many Flatreef chromitite stringers and seams (Fig. 10) that could result from fluid-driven partial melting and recrystallisation of pyroxenite (Boudreau 1988; Nicholson and Mathez 1991).

The origin of the $\mathrm{Cr}$ stringers has remained particularly controversial since Lee et al. (1983) proposed a secondary origin for $\mathrm{Cr}$ stringers enveloping pyroxenite aggregates of the "Boulder Bed" and bracketing the Merensky pegmatoid. Analogous chromite envelopes have been described in Flatreef pyroxenite lenses (Grobler et al. 2019). Chromite grains in the Merensky $\mathrm{Cr}$ stringers have highly irregular, amoeboidal textures previously explained by annealing (Eales and Reynolds 1986), corrosion (Cawthorn and Boerst 2006; Hutchinson et al. 2015), or supercooling (Vukmanovic et al. 2013). Scoon and Costin (2018) reported that the stringers can be enriched in phlogopite and rutile, and that plagioclase in the stringers tends to be reversed zoned and has higher An content than plagioclase in the adjacent hostrocks, with some values exceeding $\mathrm{An}_{90}$. Some of these observations have also been made for the Lone $\mathrm{Cr}$ stringer within the footwall of the Merensky Reef of the WBC (Maier and Eales 1997). Boudreau (1988) and Nicholson and Mathez (1990) proposed that the Cr stringers crystallised from a volatile-rich melt, consistent with the presence of mica in some stringers. In contrast, Scoon and Costin (2018) argued that the $\mathrm{Cr}$ stringers formed through partial melting of gabbronorite or anorthosite caused by late-stage intrusion of ultramafic sills, with chromite precipitating from the hybrid contact melt (cf O'Driscoll et al. 2010). However, some Bushveld $\mathrm{Cr}$ stringers such as the Lone $\mathrm{Cr}$ stringer (Maier and Eales 1997) occur within anorthosite or norite where a potential heat source that might have triggered melting is not apparent.

Kennedy et al. (2018) have proposed a recrystallisation model for the Troctolite Unit in the Bushveld northern lobe. 

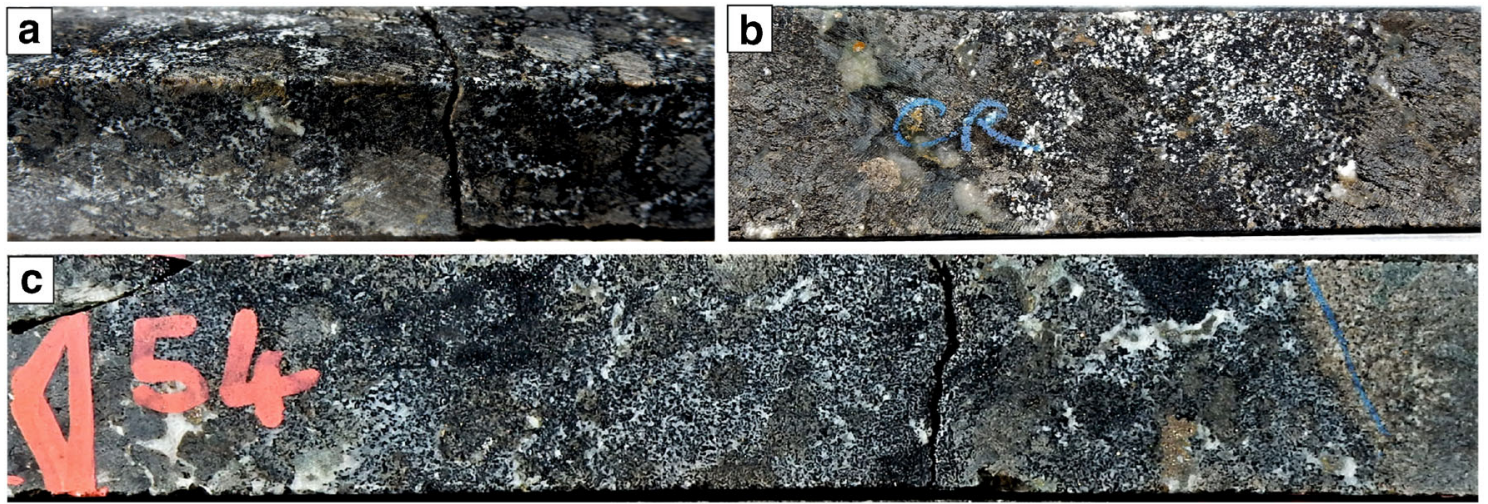

Fig. 10 Drill core (NQ core) photographs of irregular lenses and pods enriched in chromite and interstitial plagioclase within M2. a Drill core UMT341D, 699.6 m, b UMT411 723.6, c UMT421 1082.4

It is possible that other olivine-rich lithologies in the northern lobe and elsewhere in the Bushveld formed in an analogous manner. For example, in the WBC, the so-called "Pseudoreefs" consist of coarse-grained pegmatoidal troctolites or harzburgites with large subhedral or anhedral olivine grains set in a matrix of interstitial plagioclase and/or orthopyroxene (Eales et al. 1988; Maier and Eales 1997) resembling $\mathrm{M}_{\mathrm{L}}$ in the Flatreef. Similarly, the PGE reefs of the Waterberg project in the Bushveld northern lobe (Kinnaird et al. 2017) are hosted in relatively coarse-grained troctolites, with olivine predominantly associated with interstitial plagioclase, and strongly recrystallised sulfides showing disequilibrium textures, lobate grain boundaries, and alteration with abundant magnetite veins.

One unresolved aspect of the recrystallisation model is that few obvious melt/fluid channels are evident. The Merensky Reef may contain sub-vertical plagioclase-rich veins (Barnes and Maier 2002), but in general these are rare. Our interpretation is that hydrous melt could have migrated along inclined bedding contacts (Fig. 11) to end up in the peripheral portions of the complex that are now eroded. Bedding-parallel flux of volatile-rich melt or fluids and resulting autometasomatism within layers could explain the sharp changes in mobile ITE contents (Rb, K, LREE, C) between adjacent layers and the upward increase in these elements within layers, resulting from trapping at the upper contacts of layers (Fig. 12).

\section{Mobility of sulfide during cumulate recrystallisation}

In both the Flatreef and the Merensky Reef of the WBC, the PGE mineralisation commonly extends into the floor rocks of the reefs (Fig. 13). However, in the WBC, sulfides are typically confined to the uppermost few centimetres to decimetres of the footwall (Barnes and Maier 2002), whereas in the Flatreef, the mineralisation extends for up to several $10 \mathrm{~s}$ of metres into the floor (UTM231, 232, 263, and 345). Furthermore, in the case of the Flatreef, PGE also occur within calcilicate floor rocks (UTM449, 421, and 417). In the WBC, the Merensky footwall mineralisation is normally interpreted to have resulted from late-magmatic percolation of sulfide melt (Leeb-du Toit 1986; Barnes and Maier 2002; Roberts et al. 2007; Naldrett et al. 2009). The more pervasive nature of footwall mineralisation in the Flatreef could thus suggest that late-magmatic sulfide mobility played a relatively more important role. The model is consistent with textural evidence from micro XRF (Fig. 3), suggesting that sulfides are strongly interconnected in $3 \mathrm{D}$ and represent networks of sulfide liquid percolating down, and displacing silicate liquid percolating up (Barnes et al. 2018). Sulfide liquid percolation is also suggested by enrichment of PGE in some of the normally barren calcsilicate intervals (Abernethy et al. 2020). Relatively high $\mathrm{Pd} / \mathrm{Ir}$ and $\mathrm{Cu} / \mathrm{Ni}$ in some calcilicate samples (Abernethy et al. 2020) indicate PGE and base metal fractionation during transport. Of further importance is the observation that PGE grades decrease in a wide (up to $5 \mathrm{~m}$ ) halo around a norite vein within the M1 pyroxenite of UMT341D1 (Fig. 3). Our interpretation is that norite intruded incompletely solidified pyroxenite temporarily increasing the porosity of the rock and leading to percolation of sulfide in a down-dip, layer-parallel direction, resulting in metal poor pyroxenite.

\section{Potential explanations for the decreasing Pt/Pd with depth in the Flatreef}

The Flatreef and its footwall mineralisation is typically characterised by a broadly progressive downward decrease in $\mathrm{Pt} / \mathrm{Pd}$, from values as high as 2 in BAR and M2 (and locally the UG2), to values around or just below unity in M1, and as low as $<0.5$ in the footwall assimilation zone (Grobler et al. 2019; Fig. 4 of present study). A similar downward decrease in $\mathrm{Pt} / \mathrm{Pd}$ was documented in many other magmatic ore deposits, including the Finnish PGE-rich layered intrusions (Iljina et al. 2015), Duluth (Thériault et al. 2000), Raglan/Cape Smith (Barnes et al. 1992), and Muskox (Barnes and Francis 1995). The trends cannot be explained by sulfide percolation and associated 



Fig. 11 a Schematic model of layer formation in Bushveld UCZ, including chromitites and PGE reefs. Note presence of several fluidmigration directions: crystal slurries move downwards along top of crystal pile forming ultramafic layers (including chromitites). Feldspathic slurries move upwards, forming anorthosite (yellow arrows). Sulfides locally percolate downward from ultramafic slurries (red arrows). Hydrous fluids percolate up-dip along layer contacts (pink arrows). Harzburgites may form either in laterally moving metasomatic fronts along the compacted base of ultramafic layers (b), or through intrasill reactive flow $(\mathbf{c})$
Fig. 12 Variation in concentration of $\mathbf{a} \mathrm{MgO}$, $\mathbf{b}$ carbon, and $\mathbf{c} \mathrm{La} / \mathrm{Yb}$ in drill core UMT314. Note enrichment in C and $\mathrm{La} / \mathrm{Yb}$ within the $\mathrm{M} 1$ pegmatoids




Fig. 13 Sketch showing percolation of ultramafic slurries and sulfidic magma into the footwall of reefs, in response to layer-parallel up-dip migration of fluids and trapping of fluids below compacted ultramafic layers. In the Flatreef, abundant fluids are largely derived from floor xenoliths; whereas in the Western Bushveld Complex, fluids are largely derived from deep portions of the cumulate pile and the underlying floor. At both locations, fluid escape channels are expressed by potholes (cf Ballhaus and Stumpfl 1985)

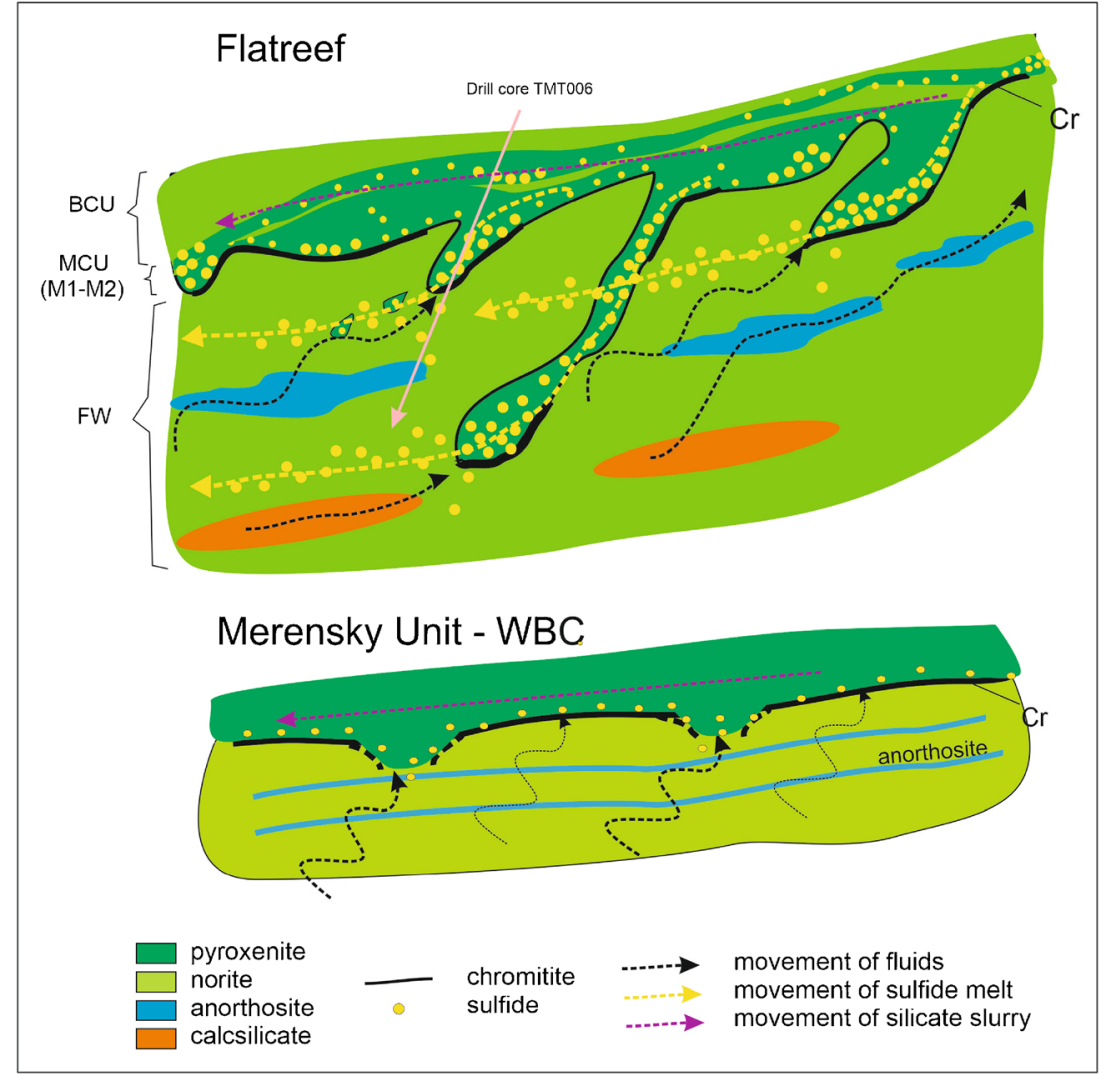

MSS crystallisation because Pt and Pd have similar D values with regard to MSS (Fleet et al. 1993).

(i) Mobility of Pd in fluids

Empirical (Barnes and Liu 2012; Holwell et al. 2017) and experimental data (Hanley 2005) indicate that at typically magmatic conditions (sulfide present, $\mathrm{fO}_{2}$ near QFM, and near neutral $\mathrm{pH}) \mathrm{Pd}$ is more mobile in fluids than Pt. Based on these data, one could suggest that any fluids migrating through the basal portions of layered intrusions were enriched in Pd relative to Pt (Boudreau 2019). Palladium could precipitate in sulfiderich rocks, potentially offering an explanation for the relatively high Pd/Ir and Pd/Pt of the lower Flatreef (Fig. 8f). However, the Flatreef rocks show good correlations between individual PGE in binary variation diagrams (Figs. 7 and 8) providing little evidence for significant selective PGE mobility.

(ii) Variable partitioning of PGE into sulfide

Several experimental studies have shown higher partitioning of Pd than Pt into sulfide melt (Barnes and Lightfoot 2005 and references therein). This could result in the residual melts becoming relatively Pt enriched, resulting in progressively more Pt-rich sulfides with height (Fig. 4).

(iii) Pt depletion of earliest Flatreef magma pulses

The earliest Flatreef pulses could have been relatively Pt depleted due to Pt alloy fractionation prior to final emplacement, in response to contamination with reduced (graphitebearing) sedimentary rocks of the Duitschland Formation. Borisov and Palme (1997) have shown that Pt solubility is positively correlated to oxygen fugacity.

\section{Summary and conclusions}

The growing body of information including the new data presented in this paper suggests that the PGE-Ni-Cu ore deposits of the Flatreef formed through a combination of magmatic, hydrodynamic and hydromagmatic processes, starting with (i) the influx of several batches of PGE fertile basaltic magma. The magmas became saturated in an immiscible sulfide melt due to assimilation of country rock sulfides during emplacement resulting in somewhat higher $\mathrm{Cu}$ contents of the Flatreef than in the reefs of the remainder of the Bushveld. 
Assimilation was particularly pronounced in the initial magma batches from which the lower portion of the Flatreef crystallised. Sulfides in these rocks are relatively Pd enriched, possibly due to higher $D_{\text {sulfide melt/silicate melt }}$ of $\mathrm{Pd}$ than $\mathrm{Pt}$, mobility of Pd in late- and post-magmatic fluids or Pt depletion of the earliest magma pulses resulting from Pt alloy fractionation triggered by contamination with reducing country rocks. We do not subscribe to the model of entrainment of PGE-rich sulfides from a staging chamber, mainly because all of the fine-grained marginal rocks to the intrusion that are generally considered to represent the parent magmas to the cumulates are sulfide undersaturated. (ii) Deposition of a thick pile of mafic-ultramafic cumulates caused subsidence of the magma chamber. Aided by flux of volatiles from the crystallising cumulates and the devolatising country rocks, subsidence and associated seismicity facilitated slumping of crystal slurries located at the top of the growing cumulate pile towards the centre of the Bushveld lopolith and into local troughs. This resulted in sorting and compaction of the slurries, pronounced layering and localised hydrodynamic erosion of floor cumulates (Fig. 13). (iii) Contacts between compositionally and texturally distinct layers acted as traps for volatiles that ascended through the cumulate pile triggering partial melting and recrystallisation of cumulates to form pegmatoidal rocks that may be highly enriched in sulfides, secondary olivine and, in some cases, graphite and phlogopite. (iv) The partial melting of the Flatreef cumulates facilitated downward percolation of sulfides, locally for up to several $10 \mathrm{~s}$ of metres. In places, ultramafic cumulates injected into their fluidised, volatile-rich footwall rocks forming extensive sill-like apophyses (Fig. 13). The combination of these processes resulted in pervasively recrystallised (zone refined) cumulate packages hosting exceptionally thick PGE mineralised intervals (up to more than $300 \mathrm{~m}$ at $>1 \mathrm{ppm}$ PGE).

Acknowledgements The authors acknowledge the permission to publish, financial support from Ivanhoe Mines Ltd, and the continuous enthusiastic support from senior company management, Stephen Torr and Dr. Patricia Makhesha in particular. We appreciate the constructive reviews by Ed Marthez, Alan Boudreau, and Pedro Jugo, as well as journal editor Georges Beaudoin which led to significant improvements in the paper. Alexandra Crossingham is thanked for producing some of the diagrams.

Open Access This article is licensed under a Creative Commons Attribution 4.0 International License, which permits use, sharing, adaptation, distribution and reproduction in any medium or format, as long as you give appropriate credit to the original author(s) and the source, provide a link to the Creative Commons licence, and indicate if changes were made. The images or other third party material in this article are included in the article's Creative Commons licence, unless indicated otherwise in a credit line to the material. If material is not included in the article's Creative Commons licence and your intended use is not permitted by statutory regulation or exceeds the permitted use, you will need to obtain permission directly from the copyright holder. To view a copy of this licence, visit http://creativecommons.org/licenses/by/4.0/.

\section{References}

Abernethy K (2020) Geochemistry and petrology of the Flatreef, as exposed in deep drill cores UMT 081 and 94, PhD thesis, Cardiff University, 309pp

Abernethy K, Maier D, Grobler D, Barnes S-J (2020) Lithogeochemistry of the Flatreef and its floor rocks as intersected by deep drill core UMT081. Min Deposita, special issue

Baglow N, Brandl G (2009) The geology to the east of Mokopane, explanation to sheet 2429AA, Council for Geoscience, South Africa

Baker SR, Boudreau AE (2019) The influence of the thick banded series anorthosites on the crystallization of the surrounding rock of the Stillwater Complex, Montana. Contrib Mineral Petrol 174. https:// doi.org/10.1007/s00410-019-1635-x

Ballhaus CG, Stumpfl EF (1985) Occurrence and petrological significance of graphite in the Upper Critical Zone, western Bushveld Complex, South Africa. Earth Planet Sci Lett 74(1):58-68

Ballhaus CG, Stumpfl EF (1986) Sulfide and platinum mineralization in the Merensky Reef: evidence from hydrous silicates and fluid inclusions. Contributions to Mineralogy and Petrology 94: 193-204

Barnes S-J, Francis D (1995) The distribution of platinum-group elements, nickel, copper, and gold in the Muskox layered intrusion, Northwest Territories, Canada. Econ Geol 90(1):135-154

Barnes S-J, Lightfoot PC (2005) Formation of magmatic nickel-sulfide ore deposits and processses affecting their copper and platinumgroup element contents. Economic Geology 100th Anniversary, $179-213$

Barnes SJ, Liu W (2012) Pt and Pd mobility in hydrothermal fluids: evidence from komatiites and from thermodynamic modelling. Ore Geol Rev 44:49-58

Barnes S-J, Maier WD (1999) The fractionation of Ni, Cu and the noble metals in silicate and sulfide melts. In: Keays RR, Lesher CM, Lightfoot PC, Farrow CEG (eds) Dynamic processes in magmatic ore deposits and their application in mineral exploration, vol 13. Geological Association of Canada, Short Course Notes

Barnes S-J, Maier WD (2002) Platinum-group elements and microstructures of Normal Merensky Reef from impala platinum mines, Bushveld Complex. J Petrol 43:103-128

Barnes S-J, Picard C, Giovenazzo D, Tremblay C (1992) The composition of nickel-copper sulphide deposits and their host rocks from the cape Smith Fold Belt, Northern Quebec. Australian J Earth Sci 39: 335-347

Barnes S-J, Zientek M, Severson MJ (1997) Ni, Cu, Au and platinum group element contents of sulfides associated with intraplate magmatism: a synthesis. Can J Earth Sci 34:337-351

Barnes S-J, Maier WD, Curl E (2010) Composition of the marginal rocks and sills of the Rustenburg layered suite, Bushveld Complex, South Africa: implications for the formation of the platinum -group element deposits. Econ Geol 105:1481-1511

Barnes SJ, Staude S, Le Vaillant M, Piña R, Lightfoot PC (2018) Sulfidesilicate textures in magmatic Ni-Cu-PGE sulfide ore deposits: massive, semi-massive and sulfide-matrix breccia ores. Ore Geol Rev 101:629-651

Bédard JP, Sparks RSJ, Renner R, Cheadle MJ, Hallworth MA (1988) Peridotite sills and metasomatic gabbros in the eastern layered series of the Rhum complex. J Geol Soc Lond 145:207-224

Borisov A, Palme H (1997) Experimental determination of the solubility of platinum in silicate melts. Geochimica et Cosmochimica Acta, 61: $4349-4357$

Boudreau AE (2008) Modelling the Merensky Reef, Bushveld Complex, Republic of South Africa. Contrib Mineral Petrol 156:431-437

Boudreau AE (2016a) The Stillwater Complex, Montana-overview and the significance of volatiles. Mineralog Mag 80(4):585-637 
Boudreau AE (2016b) Bubble migration in a compacting crystal-liquid mush. Contrib Mineral Petrol 171(4):32

Boudreau A (2019) Hydromagmatic processes and platinum-group element deposits in layered intrusions. Cambridge University Press, $275 \mathrm{pp}$.

Boudreau AE, McCallum IS (1992) Concentration of platinum-group elements by magmatic fluids in layered intrusions. Econ Geol 87: 1830-1848

Boudreau AE, Meurer WP (1999) Chromatographic separation of the platinum-group elements, gold, base metals and sulfur during degassing of a compacting and solidifying igneous crystal pile. Contrib Mineral Petrol 134:174-185

Cawthorn RG, Boerst K (2006) Origin of pegmatitic pyroxenite in the Merensky Unit, Bushveld Complex, South Africa. J Petrol 47:1509 1530

Cawthorn RG, Davies G (1983) Experimental data at 3 Kbars pressure on parental magma of the Bushveld Complex. Contrib Mineral Petrol $83: 128-135$

Chistyakova S, Latypov R, Youlton K (2019) Multiple Merensky Reef of the Bushveld Complex, South Africa. Contributions to Mineralogy and Petrology 174: 26.

Czamanske GK, Scheidle DL (1985) Characteristics of banded-series anorthosites. In: Stillwater Complex, Montana. Montana Bureau of Mines and Geology, Special ub 92, Billings, pp 334-345

De Waal SA (1977) Carbon dioxide and water from metamorphic reactions as agents for sulfide and spinel precipitation in mafic magmas. Trans Geol Soc S Afr 80:193-196

Eales HV, Reynolds IM (1986) Cryptic variations within chromitites of the upper critical zone, northwestern Bushveld Complex. Economic Geology 81: 1056-1066

Eales HV, Field M, de Klerk WJ, Scoon RN (1988) Regional trends of chemical variation and thermal erosion in the upper critical zone, western Bushveld Complex. Mineralog Mag 52:63-79

Fleet ME, Chryssoulis SL, Stone WE, Weisener CG (1993) Partitioning of platinum group elements and $\mathrm{Au}$ in the $\mathrm{Fe}-\mathrm{Ni}-\mathrm{Cu}-\mathrm{S}$ system: experiments on the fractional crystallization of sulphide melt. Contrib Mineral Petrol 115:36-44

Forien M, Tremblay J, Barnes S-J, Burgisser A, Pagé P (2015) The role of viscous particle segregation in forming chromite layers from slumped crystal slurries: insights from analogue experiments. $\mathrm{J}$ Petrol 56(12):2425-2444

Grobler DF, Brits JAN, Maier WD, Crossingham A (2019) Litho- and chemostratigraphy of the Flatreef PGE deposit, northern Bushveld Complex. Mineral Deposita 48:1-56. https://doi.org/10.1007/ s00126-012-0436-1

Hanley J (2005) The aqueous geochemistry of the platinum-group elements (PGE) in surficial, low-T hydrothermal and high-T magmatic hydrothermal environments Ottawa. In: Mungall JE (ed) Exploration for platinum-group element deposit: Mineralog Assoc Can Short Course Series, vol 35, pp 35-56

Holness MB, Hallworth MA, Woods A, Sides RE (2006) Infiltration metasomatism of cumulates by intrusive magma replenishment: the Wavy Horizon, Isle of Rum, Scotland. J Petrol 48(3):563-587

Holwell DA, Boyce AJ, McDonald I (2007) Sulfur isotope variations within the Platreef Ni-Cu-PGE deposit: genetic implications for the origin of sulfide mineralization. Econ Geol 102:1091-1110

Holwell, D. A., McDonald, I., \& Butler, I. B. (2011). Precious metal enrichment in the Platreef, Bushveld Complex, South Africa: evidence from homogenized magmatic sulfide melt inclusions. Contributions to Mineralogy and Petrology, 161(6), 1011-1026.

Holwell DA, Adeyemi Z, Ward LA, Smith DJ, Graham SD, McDonald I, Smith JW (2017) Low temperature alteration of magmatic Ni-CuPGE sulfides as a source for hydrothermal Ni and PGE ores: a quantitative approach using automated mineralogy. Ore Geol Rev 91:718-740

Howell PD, van der Pluijm BA (1999) Structural sequences and style of subsidence in the Michigan basin. Geol Soc Am Bull 111:974-991

Hunt E, Latypov R, Horváth P (2018) The Merensky cyclic unit, Bushveld Complex, South Africa: reality or myth? Minerals 8(4): 144

Hutchinson D, Foster J, Prichard H, Gilbert S (2015) Concentration of particulate platinum-group minerals during magma emplacement; a case study from the Merensky Reef, Bushveld Complex. Journal of Petrology 56: 113-159

Iljina M, Maier WD, Karinen T (2015) PGE-(Cu-Ni) deposits of the Tornio-Näränkävaara belt of intrusions (Portimo, Penikat, and Koillismaa). In mineral deposits of Finland (pp. 133-164). Elsevier

Irvine TN, Andersen JCØ, Brooks CK (1998) Included blocks (and blocks within blocks) in the Skaergaard intrusion: Geologic relations and the origins of rhythmic modally graded layers. Geological Society of America Bulletin 110: 1398-1447

Karykowski B, Maier WD (2017) Microtextural characterisation of the Lower Zone in the western limb of the Bushveld Complex, South Africa: evidence for extensive melt migration within a sill complex. Contrib Min Petrol 172. https://doi.org/10.1007/s00410-017-1380-y

Kennedy B, McDonald I, Tanner D, Longridge L (2018) The Troctolite unit of the northern limb; PGE enrichment and mineralisation. (Abst), 13th Int Plat Symp, Polokwane, South Africa, 92-93

King Hubbert M, Rubey WW (1959) Role of fluid pressure in mechanics of overthrust faulting: I. mechanics of fluid-filled porous solids and its application to overthrust faulting. Geol Soc Amer Bull 70(2): 115-166

Kinnaird JA, Kruger FJ, Nex PAM, Cawthorn RG (2002) Chromitite formation - a key to understanding processes of platinum enrichment. Appl Earth Sci 111:B23-B35. https://doi.org/10.1179/aes. 2002.111.1.23

Kinnaird JA, Yudovskaya MA, McCreesh MJG, Huthmann FM, Botha TJ (2017) The Waterberg PGE deposit - a typical mineralization in mafic-ultramafic rocks of the Bushveld Complex, South Africa. Econ Geol 112:1367-1394

Lai Z, Vallejo LE, Zhou W, Ma G, Espitia JM, Caicedo B, Chang X (2017) Collapse of granular columns with fractal particle size distribution: Implications for understanding the role of small particles in granular flows. Geophysical Research Letters 44:12-181

Larsson DH, Takman PA, Lundström U, Burvall A, Hertz HM (2011) A $24 \mathrm{keV}$ liquid-metal-jet x-ray source for biomedical applications. Rev Sci Instrum 82(12):123701

Latypov R, Chistyakova S, Barnes SJ, Hunt EJ (2017) Origin of platinum deposits in layered intrusions by in situ crystallization: evidence from undercutting Merensky reef of the Bushveld Complex. J Petrol 58:715-762

Latypov R, Chistyakova S, McIntosh R, Scogings A (2018) Geochemical evidence for in situ growth of LG6 chromitite from the compositionally stratified magma in the Bushveld chamber. (Abst), 13th Int Plat Symp, Polokwane, South Africa, 103-104

Lee CA (1996) A review of mineralization in the Bushveld Complex and some other layered intrusions. In In: Cawthron RG (ed) Layered intrusions. Elsevier, Amsterdam, pp 103-145

Lee CA, Irvine TN, Viljoen EA (1983) Reaction chromitites (abstract). Symposium Bushveld Complex, Geol Soc S Afr, Pretoria, pp. 60 62

Leeb-du Toit A (1986) The impala platinum mines. In: Anhaeusser CR, Maske S (eds) Mineral deposits of southern Africa. Geol Soc S Afr, Johannesburg, pp 1091-1106

Lesher CE, Spera FJ (2015) Thermodynamic and transport properties of silicate melts and magma. 113e141. In: Sigurdsson H, Houghton B, 
McNutt S, Rymer H, Stix J (eds) The encyclopedia of volcanoes. Academic Press, 1422pp

Li C., Ripley E.M., Sarkar A., Shin D. and Maier WD (2005) Origin of phlogopite-orthopyroxene inclusions in chromites from the Merensky Reef of the Bushveld Complex, South Africa. Contributions to Mineralogy and Petrology 150: 119-130

Maier WD (1995) Olivine oikocrysts in Bushveld anorthosite: some implications for cumulate formation. Can Miner 33:1011-1022

Maier WD, Barnes S-J (2008) Platinum-group elements in the UG1 and UG2 chromitites and the Bastard reef at impala platinum mine, western Bushveld Complex. S Afr J Geol 111:159-176

Maier WD, Eales HV (1997) Correlation within the UG2-Merensky Reef interval of the Western Bushveld Complex, based on geochemical, minrelogical and petrological data. Bulletin 20. Council for Geoscience: $56 \mathrm{pp}$

Maier WD, Barnes S-J, Groves DI (2013) The Bushveld Complex, South Africa: formation of platinum-palladium, chrome and vanadiumrich layers via hydrodynamic sorting of a mobilized cumulate slurry in a large, relatively slowly cooling, subsiding magma chamber. Miner Deposita 48:1-56

Maier WD, Howard HM, Smithies RH, Yang SH, Barnes S-J, O'Brien H, Huhma H, Gardoll S (2015) Magmatic ore deposits in maficultramafic intrusions of the Giles event, Western Australia. Ore Geol Rev 71:405-436

Maier WD, Barnes S-J, Karykowski BT (2016a) A chilled margin of komatiite and $\mathrm{Mg}$-rich basaltic andesite in the western Bushveld Complex. S Afr Contrib Miner Petrol 171. https://doi.org/10.1007/ s00410-016-1257-5

Maier WD, Karykowski BT, Yang SH (2016b) Formation of transgressive anorthosite seams in the Bushveld Complex via tectonically induced mobilisation of plagioclase-rich crystal mushes. Geosci Front 7:875-889

Maier WD, Jugo P, Yudovskaya M (2020) Introduction paper to thematic issue on the Flatreef PGE deposit, northern Bushveld Complex. Mineral Deposita special issue Intro paper

Marquis E (2015) Petrogenesis of the Harzburgitic to troctolitic units in the Turfspruit Cyclic Unit, Northern Bushveld Complex, South Africa. MESci Geology Thesis. Cardiff University, $255 \mathrm{pp}$

Mathez EA (1995) Magmatic metasomatism and formation of the Merensky reef, Bushveld Complex. Contrib Mineral Petrol 119: 277-286

Mathez EA, Kinzler RJ (2017) Metasomatic chromitite seams in the Bushveld and rum intrusions. Elements 13:397-402

McDonald I, Holwell DA (2007) Did lower zone magma conduits store PGE-rich sulphides that were later supplied to the Platreef? S Afr J Geol 110:611-616

Mitchell AA, Henckel J, Mason-Apps A (2019) The Upper Critical Zone of the Rustenburg layered suite in the Swartklip sector, northwestern Bushveld Complex, on the farm Wilgerspruit 2JQ: I. Stratigraphy and PGE mineralization patterns, SAJG (in press)

Naldrett AJ, Wilson A, Kinnaird J, Chunnett G (2009) PGE tenor and metal ratios within and below the Merensky Reef, Bushveld Complex: implications for its genesis. J Petrol 50:625-659

Nicholson DM, Mathez EA (1991) Petrogenesis of the Merensky Reef in the Rustenburg section of the Bushveld Complex. Contrib Mineral Petrol 107:293-309

NIST-National Institute of Standards and Technology (2012) Standard reference material 1243 (Ni-Cr-Co alloy UNS N07001) certificate of analysis. Dept. of Commerce, Gaithersburg

O’Driscoll B, Emeleus CH, Donaldson CH, Daly JS (2010) Cr-spinel seam petrogenesis in the rum layered suite, NW Scotland: cumulate assimilation and in situ crystallization in a deforming crystal mush. $\mathrm{J}$ Petrol 51:1171-1201
Peters BF, Parker HM, Kuhl T, Joughin W, Lawson M, Coetzee V, Smith G (2016) Platreef project. Platreef 2016 Resource Technical Report. NI 43-101 published on www.sedar.com. Effective date 22 April 2016, 509pp

Roberts MD, Reid DL, Miller JA, Basson IJ, Roberts M, Smith D (2007) The Merensky Cyclic Unit and its impact on footwall cumulates below Normal and Regional Pothole reef types in the Western Bushveld Complex. Mineralium Deposita 42: 271-292

Ryan CG (2000) International journal of imaging systems and technology, special issue on "Advances in Quantitative Image Analysis", 11: 219-230

Ryan CG, Kirkham R, Moorhead GF, Parry D, Jensen M, Faulks A, Hogan S, Dunn PA, Dodanwela R, Fisher LA, Pearce M (2018) Maia mapper: high definition XRF imaging in the lab. J Instrum 13(03):C03020

Schannor M, Veksler IV, Hecht L, Harris C, Romer RL, Manyeruke TD (2018) Small-scale Sr and O isotope variations through the UG2 in the eastern Bushveld Complex: the role of crustal fluids. Chem Geol 485:100-112

Scoates JS, Wall CJ (2015) Geochronology of layered intrusions. In: Charlier B et al (eds) Layered intrusion,ns. Springer Science, Dordrecht, pp 3-74

Scoon RN, Costin G (2018) Chemistry, morphology and origin of magmatic-reaction chromite stringers associated with anorthosite in the upper critical zone at Winnaarshoek, eastern limb of the Bushveld Complex. J Petrol 59:1551-1578

Siddons DP, Kirkham R, Ryan CG, De Geronimo G, Dragone A, Kuczewski AJ, Li ZY, Carini GA, Pinelli D, Beuttenmuller R, Elliott D (2014) Maia X-ray microprobe detector array system. In Journal of Physics: Conference Series (Vol. 499, No. 1, p. 012001). IOP Publishing

Solano JMS, Jackson MD, Sparks RSJ, Blundy J (2014) Evolution of major and trace element composition during melt migration through crystalline mush: implications for chemical differentiation in the crust. Amer J Sci 314:895-939

Teigler B, Eales HV (1996) The Lower and Critical Zones of the Western Limb of the Bushveld Complex as intersected by the Nooitgedacht boreholes. Bulletin 111. Council for Geoscience, 126pp

Thériault RD, Barnes S-J, Severson MJ (2000) Origin of Cu-Ni-PGE sulfide mineralization in the partridge river intrusion, Duluth Complex, Minnesota. Econ Geol 95:929-943

Viljoen MJ (1999) The nature and origin of the Merensky Reef of the western Bushveld Complex based on geological facies and geophysical data. S Afr J Geol 102:221-239

Vukmanovic Z, Barnes SJ, Reddy SM, Godel B, Fiorentini ML (2013) Morphology and microstructure of chromite crystals in chromitites from the Merensky Reef (Bushveld Complex, South Africa). Contributions to Mineralogy and Petrology 165: 1031-1050

Vukmanovic Z, Holness MB, Monks K, Andersen JCØ (2018) The Skaergaard trough layering: sedimentation in a convecting magma chamber. Contrib Mineral Petrol 173:1-18

Vukmanovic Z, Holness M, Roberts R (2019) The creation and evolution of crystal mush in the Upper Zone of the Rustenburg layered suite, Bushveld Complex, South Africa. J Petrol 60(8):1523-1542

Wallmach T, Hatton CJ, Droop GTR (1989) Extreme facies of contact metamorphism developed in calc silicate xenoliths in the eastern Bushveld Complex. Casn Min 27:509-523

Yudovskaya MA, Kinnaird JA, Sobolev AV, Kuzmin DV, McDonald I, Wilson AH (2013) Petrogenesis of the Lower Zone olivine-rich cumulates beneath the Platreef and their correlation with recognized occurrences in the Bushveld Complex. Economic Geology 108: 1923-1952

Yudovskaya MA, Kinnaird JA, Grobler D, Costin G, Abramova VD, Dunnett T, Barnes S-J (2017a) Zonation of Merensky style platinum 
mineralization in Turfspruit thick Reef Facies (Northern limb of the Bushveld Complex). Econ Geol 112:1333-1365

Yudovskaya M, Belousova E, Kinnaird J, Dubinina E, Grobler DF, Pearson N (2017b) Re-Os and S isotope evidence for the origin of Platreef mineralization (Bushveld Complex). Geochim Cosmochim Acta 214:282-307

Zhitova LM, Kinnaird JA, Gora MP, Shevkoa EP (2016) Magmatogene fluids of metal-bearing reefs in the Bushveld Complex, South
Africa: based on research data on fluid inclusions in quartz. Geology of Ore Deposits 58:58-81

Publisher's note Springer Nature remains neutral with regard to jurisdictional claims in published maps and institutional affiliations. 